\title{
Possible Jurassic age for part of Rakaia Terrane: implications for tectonic development of the Torlesse accretionary prism
}

\author{
PETER J. J. KAMP \\ Department of Earth Sciences \\ The University of Waikato \\ Private Bag 3105 \\ Hamilton, New Zealand
}

\begin{abstract}
Greywacke sandstone and argillite beds comprising Rakaia Terrane (Torlesse Complex) in mid Canterbury, South Island, New Zealand, are widely regarded as Late Triassic (Norian) in age based on the occurrence of Torlessia trace fossils, Monotis, and other taxa. This paleontological age assignment is tested using published ${ }^{40} \mathrm{Ar} /{ }^{39} \mathrm{Ar}$ mica and $\mathrm{U}-\mathrm{Pb}$ zircon ages for these rocks and published and new zircon fission track (FT) ages. The youngest $\mathrm{U}-\mathrm{Pb}$ zircon ages in the Rakaia Terrane rocks in mid Canterbury are Norian, whereas $10-20 \%$ of the ${ }^{40} \mathrm{Ar} /$ ${ }^{39} \mathrm{Ar}$ muscovite ages are younger than Norian. Numerical modelling of these mica ages shows that they cannot have originated from partial thermal overprinting in the Torlesse prism if the thermal maximum was short-lived and early in the prism history (210-190 Ma), as commonly inferred for these rocks. The young component of mica ages could, however, be explained by extended residence (200-100 Ma) at $265-290^{\circ} \mathrm{C}$ in the prism. Early Jurassic (c. $189 \mathrm{Ma}$ ) zircon FT ages for sandstone beds from Arthur's Pass, the Rakaia valley, and the Hermitage (Mt Cook) are interpreted not to have experienced maximum temperatures above $210^{\circ} \mathrm{C}$, and therefore cannot have been reduced as a result of partial annealing in the Torlesse prism. This is based on identification of a fossil Cretaceous, zircon FT, partial annealing zone in low-grade schists to the west, and the characteristics of the age data. The Early Jurassic zircon FT ages and the young component of ${ }^{40} \mathrm{Ar} /{ }^{39} \mathrm{Ar}$ mica ages are regarded therefore as detrital ages reflecting cooling in the source area, and constrain the maximum depositional age of parts of the Rakaia Terrane in mid Canterbury. The zircon FT data also show the initiation (c. $100 \mathrm{Ma}$ ) of marked and widespread Late Cretaceous cooling of Rakaia Terrane throughout Canterbury, which is attributed to uplift and erosion of inboard parts of the Torlesse prism due to continuing subduction accretion at its toe.
\end{abstract}

The critical wedge concept is proposed as a new framework for investigating the development of the Torlesse Complex. The Rakaia Terrane may have formed the core of an accretionary wedge imbricated against the New Zealand margin during the Middle or Late Jurassic. Late Jurassic nonmarine sediments (e.g., Clent Hills Formation) accumulated upon the inner parts of the prism as it enlarged,

G00016

Received 27 March 2000; accepted 19 October 2000 emerged, and continued to be imbricated. Exhumation of Otago Schist from c. 135 Ma may mark the development of a balance (steady state) between sediments entering the prism at the toe and material exiting at the inboard margin. The enlargement of the area of exhumation to all of Canterbury from c. $100 \mathrm{Ma}$ may reflect a dynamic response to widening of the prism through the accretion of Cretaceous sediments. The model of a dynamic critical wedge may help to explain the various expressions of the Rangitata Orogeny.

Keywords Torlesse Complex; Rakaia Terrane; fission track; thermochronology; tectonics; Canterbury

\section{INTRODUCTION}

The paleontologically assigned Late Permian to Late Triassic age of the Rakaia Terrane in Central and South Canterbury and North Otago (Campbell \& Warren 1965; Andrews et al. 1976; Suggate et al. 1978) (Fig. 1) is fundamental in contemporary understanding of the Mesozoic evolution of New Zealand basement. Correlations of the New Zealand stages implied by the fossil occurrences with international stages (e.g., Crampton et al. 1995) suggest that the numerical ages of these rocks range between c. $266 \mathrm{Ma}$ (mid Kazanian) and $210 \mathrm{Ma}$ (end Norian) (Gradstein et al. 1994) (Fig. 2). Significant gaps occur in the faunal sequence, however, there being no demonstrable record of Early Triassic or of very Late Triassic through Middle Jurassic strata in the Rakaia Terrane (e.g., Andrews et al. 1976).

The significance of the age of the Rakaia Terrane extends to all elements of its geology and origin. MacKinnon (1983) stated that the most convincing evidence for (subduction) accretion (in the Torlesse) is the distribution of major fossil zones. The paleontologically assigned age has been an important constraint in assessing U-Pb and ${ }^{40} \mathrm{Ar} /{ }^{30} \mathrm{Ar}$ radiometric ages bearing on likely provenance areas and the timing of post-depositional displacement histories (e.g., Adams \& Kelley 1998; Adams et al. 1998). Stratigraphic age has been an essential requirement in assessment of the thermo-tectonic history of the Rakaia Terrane based on whole-rock K-Ar and fission track (FT) ages (e.g., Adams et al. 1985; Kamp et al. 1989).

New radiometric ages on mineral phases have been published recently, which suggest that it is timely to test the longstanding Late Permian to Late Triassic age assignment given to the Rakaia Terrane, particularly in Canterbury to North Otago. In the following sections, these published ages and interpretations are discussed, and new zircon FT ages for the parts of the terrane exposed in the Rakaia valley are presented. In testing the fossil ages for the Rakaia Terrane, the general problem faced, in interpreting maximum stratigraphic ages from the radiometric ages, is the degree to which the measured ages have been partially reset in the Torlesse prism. That is, do the single-grain ages reflect only 


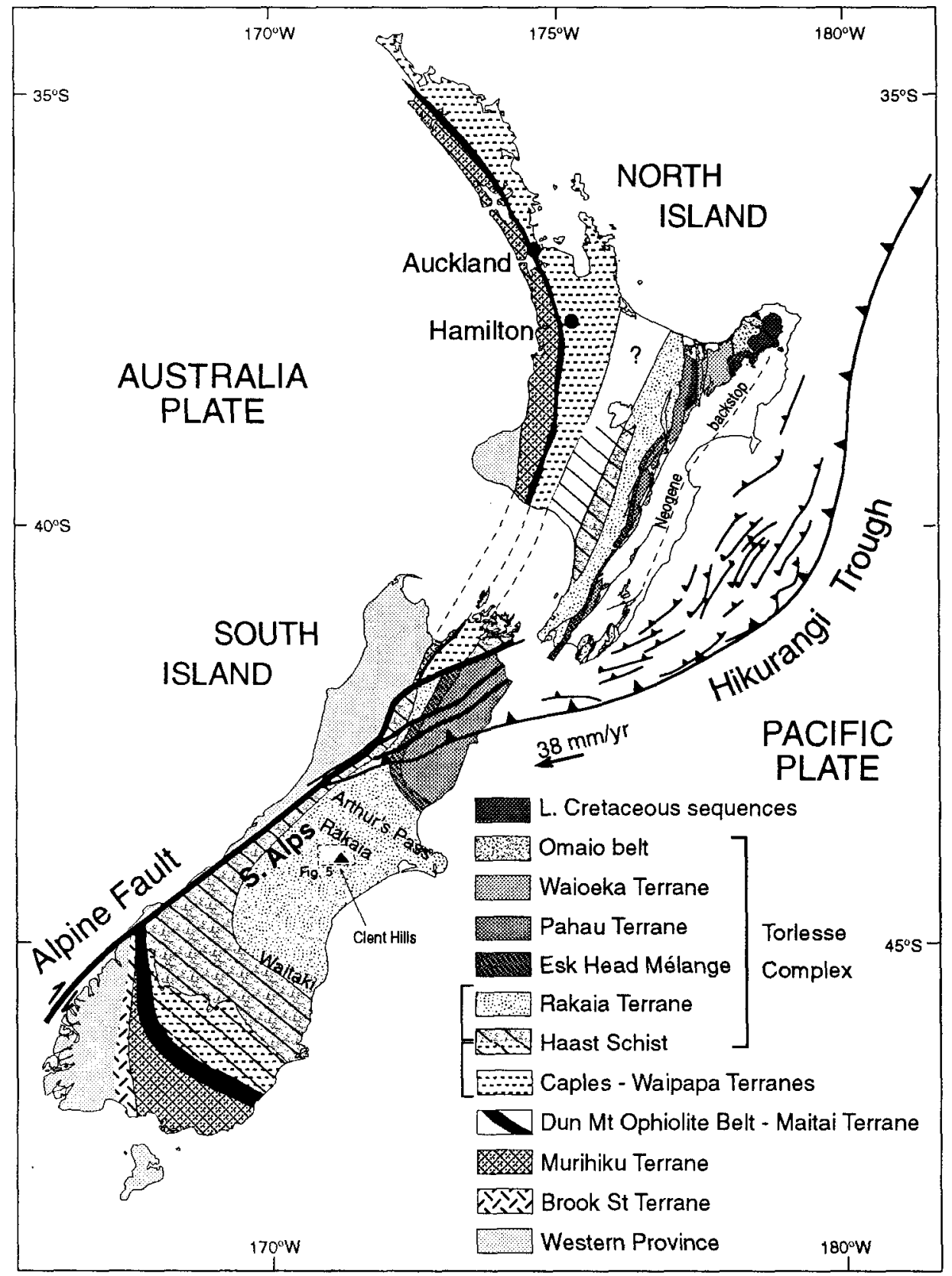

Fig. 1 Map showing generalised distribution of basement terranes in New Zealand. Redrawn from Bishop et al. (1985), Mortimer (1995), Mortimer et al. (1997), and Kamp (2000).

thermo-tectonic events (cooling) in the source area, including volcanism, or has the thermal regime in the prism lead to partial overprinting of the accumulated age through loss of daughter product, thereby reducing the measured ages to within or below the depositional age, and making the fossil ages appear too old. It is particularly difficult to establish depositional ages from low-temperature thermochronometers when the peak thermal event occurred in the prism within a few million years of deposition, as has been proposed for the Rakaia Terrane (e.g., Adams et al. 1985; Adams \& Graham 1996). This underscores the importance of considering ages derived by several thermochronometers, which enables one to assess and discriminate between the magnitude and timing of thermal events in the source area and the prism, and to constrain the depositional age. While low-temperature thermochronometers such as zircon FT and ${ }^{40} \mathrm{Ar} /{ }^{39} \mathrm{Ar}$ on biotite and muscovite are susceptible to partial overprinting and age reduction in the prism, their utility in constraining the maximum depositional age arises from their timing of the late phases of cooling/denudation in source areas. High-temperature thermochronometers (e.g., U-Pb zircon) record cooling earlier in the thermal history of the source area than low-temperature methods, and, except in the case of volcanism, will in general provide older maximum ages on deposition than ${ }^{40} \mathrm{Ar} /{ }^{39} \mathrm{Ar}$ or FT ages.

Considerations of the age of the Torlesse Complex need to be undertaken in the context of its tectonic setting and evolution. The Torlesse Complex is essentially an emergent fold-thrust belt that developed at a convergent margin through the growth of one or more submarine accretionary wedges. An improved understanding of its structural and tectonic development will be gained when it is investigated in the context of critical wedge theory (e.g., Chapple 1978; Davis et al. 1983; Dahlen 1990). This will be helped with 
TIME-SCALES

AGE OF BASEMENT TERRANES

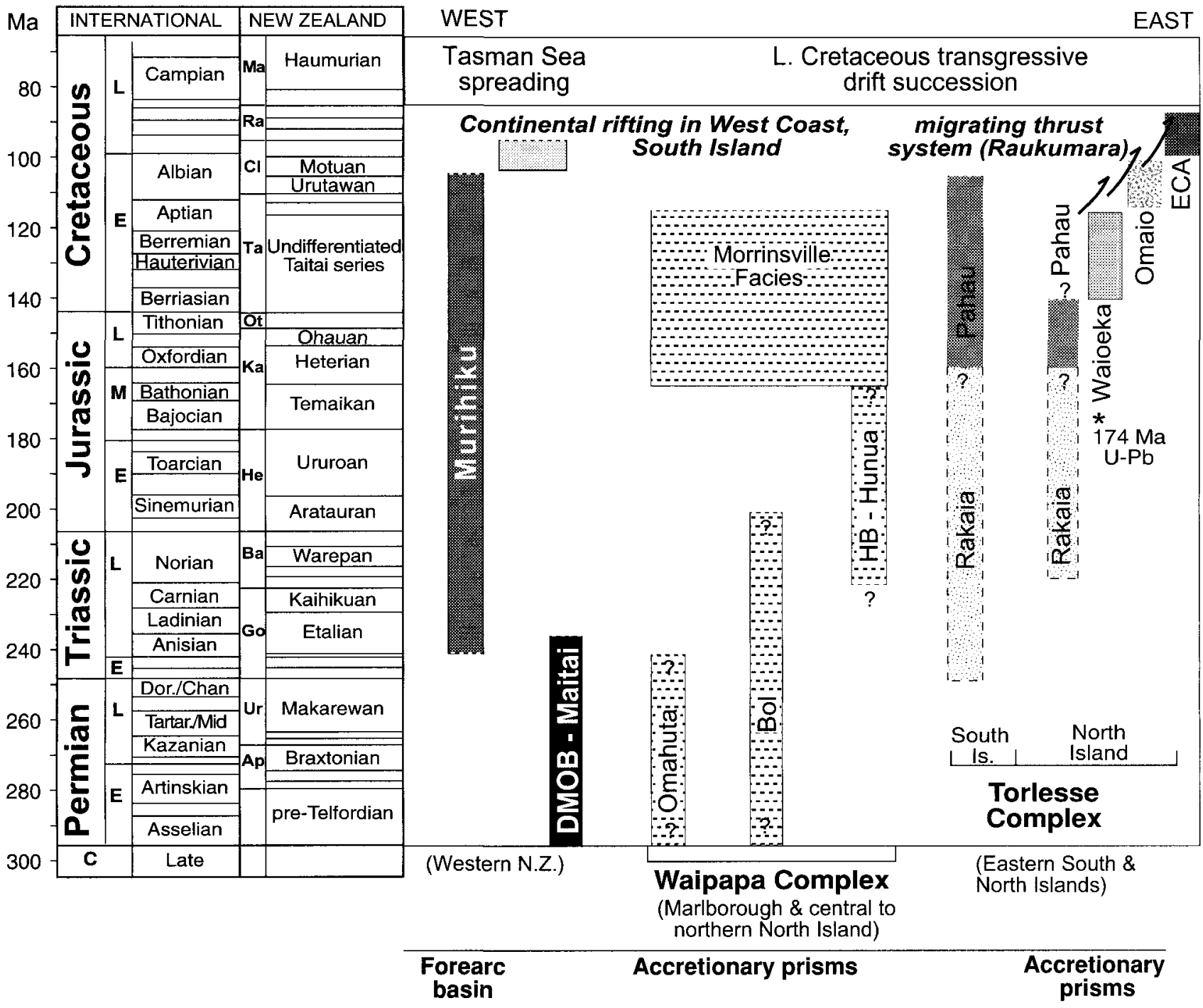

Fig. 2 Summary of age ranges of selected basement terranes making up the foundation of New Zealand. Modified from Cawood et al. (1999). The age of the Rakaia Terrane has been adjusted to extend into the Jurassic. Note the zircon U-Pb SHRIMP age of $174 \mathrm{Ma}$ reported by Lindsay et al. (1994) for the Kaimanawa Range. See text for discussion in terms of the development of the Torlesse accretionary prism.

better constraints on the following parameters: the stratigraphic age of sediments incorporated into the Rakaia and younger wedges; the residence time of material in the prism; the time it took for the prism to come to steady state; the time when the inboard margin first became erosional; and the extent and amount of erosion/exhumation across the prism. Body fossils identified to date, particularly in the Rakaia Terrane, are restricted in type, occurrence, and stratigraphic extent, and have been interpreted as indicating a very punctuated history of sediment accumulation. This is an unrealistically simple model given the volume of rock involved and the reality that the contemporary sedimentation and related subduction accretion built up the whole of the crustal section in parts of eastern New Zealand through hundreds of kilometres or more of oceanic subduction. To help move our understanding forward, application and integration of paleontological and radiometric (numerical) dating are required, where possible, for the whole of the prism to establish the parameters listed above. This will result in a better understanding of the dynamics of the prism and, as discussed here, a new context or model to explain the various expressions of the Rangitata Orogeny.

\section{ASSESSMENT AND MODELLING OF ${ }^{40} \mathrm{Ar} /{ }^{39} \mathrm{Ar}$ MUSCOVITE AGES}

Single crystal ${ }^{40} \mathrm{Ar} /{ }^{39} \mathrm{Ar}$ ages of detrital muscovite and biotite have been reported recently by Adams \& Kelley (1998) for several metagreywacke samples of Rakaia Terrane from the Wellington and Canterbury regions. The particular interest in their study was in constraining the likely provenance of the Torlesse Complex. The small percentage of grains in some samples with measured ages less than the paleontologically assigned ages of the host rocks were interpreted by them in terms of overprinting during a principal regional 
A Monotis zone, ${ }^{40} \mathrm{Ar} / 39 \mathrm{Ar}$ muscovite age components.

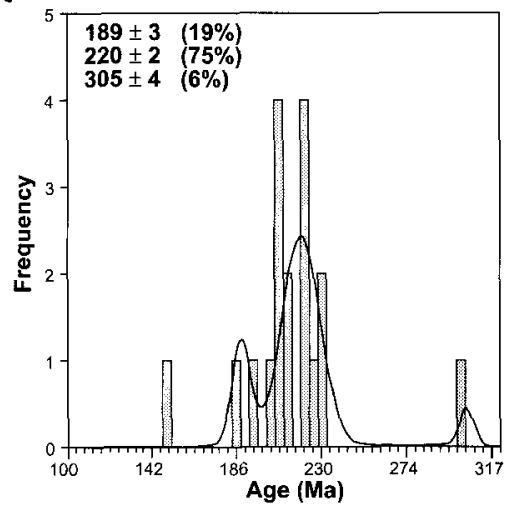

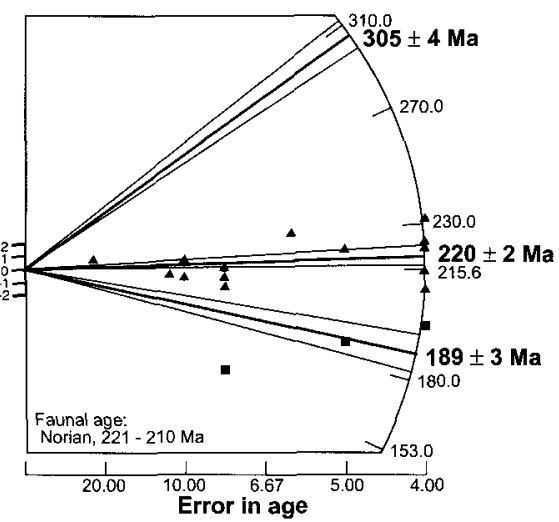

Fig. 3A-E Probability-density function graphs and radial plots of ${ }^{40} \mathrm{Ar} /{ }^{39} \mathrm{Ar}$ mica ages based on data reported in Adams \& Kelley (1998). The graphs with probability-density function curves and radial plots visualise the age components identified by mixture modelling of the published single-grain ages for samples grouped as follows. A, Otaki River (OTK1), Arthur's Pass (SIX47); B, Ngauranga Gorge (ONGQ1), Hermitage (HER3), Broken River (BKR3); C, Kapiti Island (KPT38); D, Lake Aviemore (AV1); E, Porters Pass (PP1), Arthur's Pass (SIX47).

B Norian Stage, ${ }^{40} \mathrm{Ar} / 39 \mathrm{Ar}$ muscovite age components.
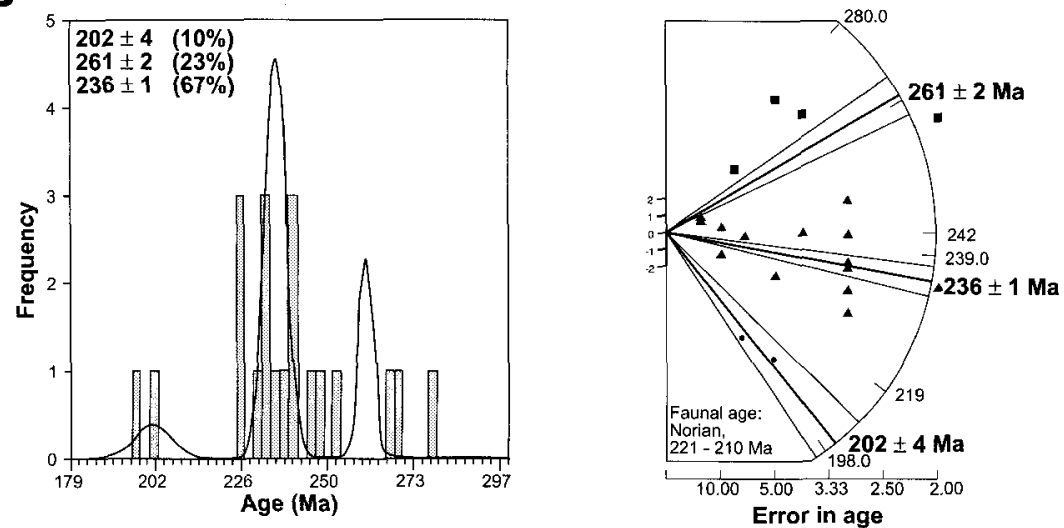

C Torlessia zone, ${ }^{40} \mathrm{Ar} / 39 \mathrm{Ar}$ muscovite age components.
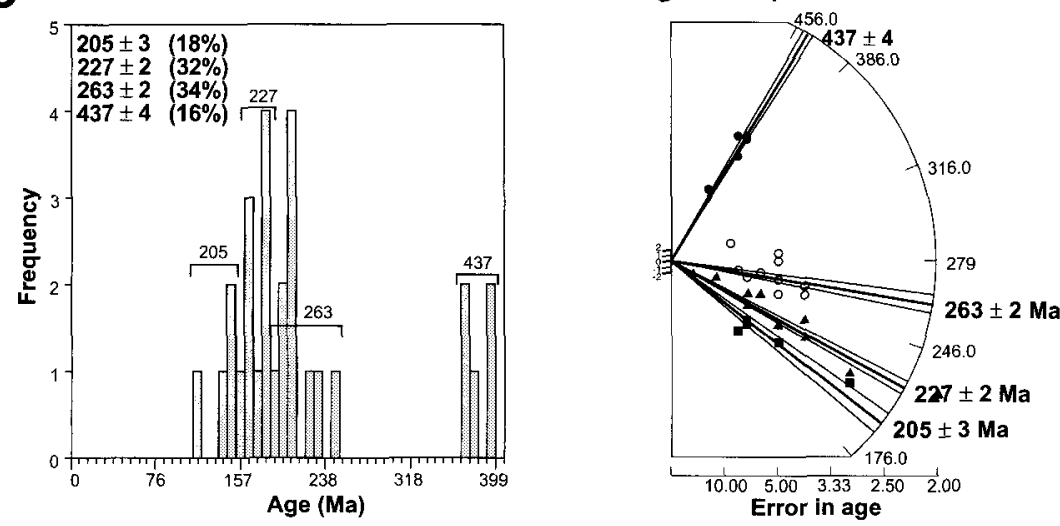

metamorphic event at $190-210 \mathrm{Ma}$, that is, very soon after deposition.

In the application of radiometric methods, the maximum depositional age is constrained most closely by the youngest measured age component, provided that age is not partially or totally overprinted. To establish the youngest age component, the ${ }^{40} \mathrm{Ar} /{ }^{39} \mathrm{Ar}$ ages reported by Adams \& Kelley (1998) have been analysed by mixture modelling, which is becoming routine in the analysis of detrital radiometric age data. The mathematical principles involved have been described fully by Sambridge \& Compston (1994), and the analyses reported here were undertaken using software provided by K. Gallagher and M. Sambridge. The technique involves calculating mean ages and associated errors for each age component in the distribution. As the number of components is prescribed in the analysis, any particular model result is non-unique. To help assess that the correct and minimum acceptable number of modes are identified, the data are illustrated as probability-density graphs (curves) over histograms of the ages, and especially on radial plots (Galbraith 1990). Radial plots are a graphical method of simultaneously displaying the age and error for multiple grains; in such graphs, the more a grain age plots to the right, the more precise its age. For FT and argon age data, more and less precise grain ages are commonly seen to be aligned away from the origin on radial plots.

Figure 3 illustrates the results of mixture modelling of the ${ }^{40} \mathrm{Ar} /{ }^{39} \mathrm{Ar}$ single grain ages reported by Adams \& Kelley (1998). The Monotis zone (Norian) diagram is represented by a combination of single grain muscovite ${ }^{40} \mathrm{Ar} /{ }^{39} \mathrm{Ar}$ ages 
Fig. 3 (continued)

D Aviemore sample, ${ }^{40} \mathrm{Ar} /{ }^{39} \mathrm{Ar}$ muscovite age components.
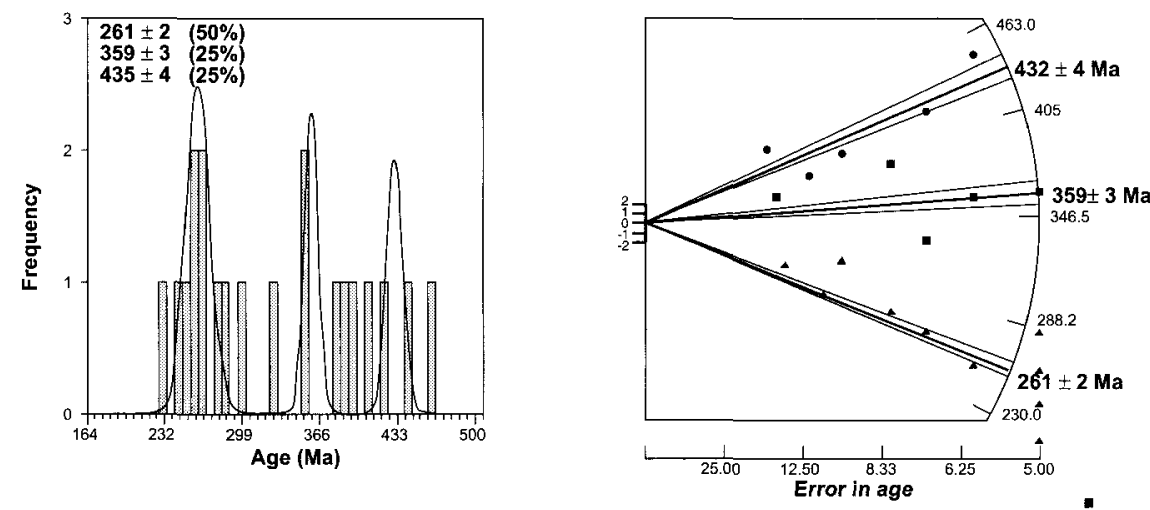

E Norian Stage, ${ }^{40 \mathrm{Ar} / 39} \mathrm{Ar}$ biotite age components.
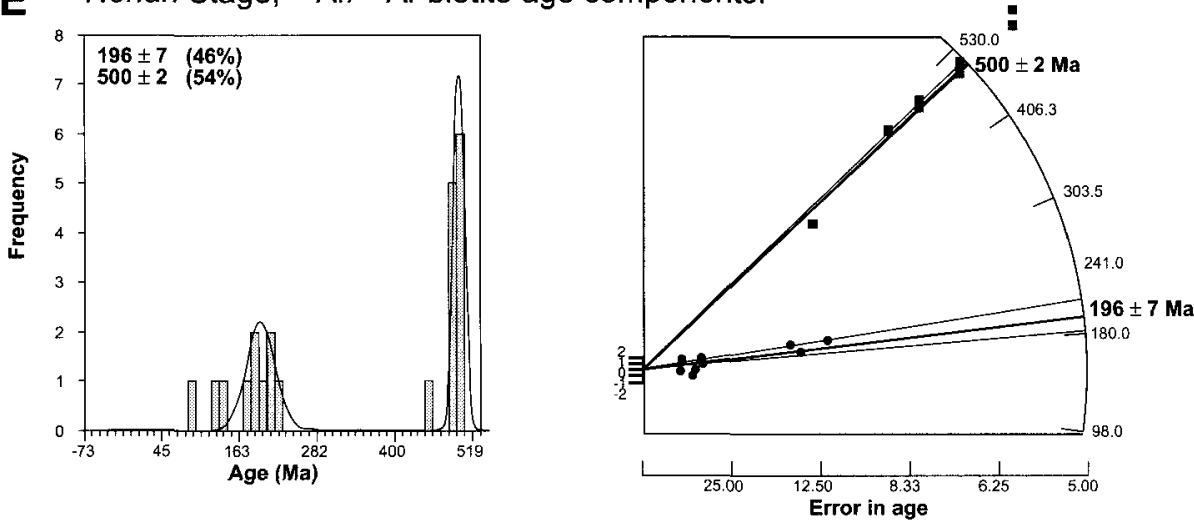

(Fig. 3A) from well-known localities at Otaki River (GrantTaylor \& Waterhouse 1963) and Arthur's Pass (MacKinnon 1980) which contain at least three components, the youngest (19\% of crystals) having a mean age of $189 \pm 3$ Ma (Early Jurassic). Betraccium-bearing (Late Norian) greywacke from Kapiti Island (Blome et al. 1987) also comprises at least three age components, the youngest (10\% of crystals) being $202 \pm 4 \mathrm{Ma}$ (Early Jurassic) (Fig. 3B). Muscovite ${ }^{40} \mathrm{Ar} /{ }^{39} \mathrm{Ar}$ ages from the Mid-Late Triassic (Campbell \& Warren 1965; Andrews et al. 1976) Torlessia faunal zone are best described by four age components (Fig. 3C), the youngest being 205 $\pm 3 \mathrm{Ma}$ ( $18 \%$ of crystals) (Early Jurassic). The data originate from localities at Ngaraunga Gorge (Wellington), the Hermitage (Mt Cook), and Broken River (Mid Canterbury). Figure 3D illustrates muscovite data from Lake Aviemore (South Canterbury), probably from within the Atomodesma Permian fossil zone. The youngest age component is $261 \pm$ 2 Ma (Late Permian).

Mixture modelling has identified at the Monotis, Betraccium, and Torlessia fossil localities a component of crystals, comprising between 10 and $19 \%$ of all those analysed, that have Early Jurassic numerical ages a few million years younger than the inferred Norian and older (Triassic) faunal ages, based on the Gradstein et al. (1994) time-scale. Does this young component of muscovite ages reflect magmatic and denudational cooling within the source area, and hence genuine detrital ages, or does it reflect age reduction as a consequence of elevated burial temperatures and partial argon retention? Adams \& Kelley (1998) favoured the latter alternative, based to a large extent on the interpretation of a principal metamorphic event affecting the older Torlesse rocks during the interval 190-210 Ma, followed by post-metamorphic uplift and cooling through to Middle Jurassic (c. $170 \mathrm{Ma}$ ) (e.g., Adams \& Graham 1996; Adams et al. 1998).

Numerical modelling using MacArgon software (Lister \& Baldwin 1996) enables estimates of the maximum temperatures required to partially overprint muscovite ${ }^{40} \mathrm{Ar} /$ ${ }^{39} \mathrm{Ar}$ to be obtained, given the time-scale of heating inferred by the Adams et al. (1998) interpretation. The approach taken follows that of Baldwin \& Lister (1998), in which numerical models were run with MacArgon for a family of possible time-temperature histories (Adams \& Graham 1996; Adams et al. 1998), differing only in the ambient maximum temperatures possibly experienced by the host rocks during the Early Jurassic. The diffusion parameters used for forward modelling of the muscovite age data are listed in the caption to Fig. 4. From the 10 different runs of the possible timetemperature histories, assuming a depositional age of 225 $\mathrm{Ma}$ and no inherited age at that time (Fig. 4A), a curve of modelled age reduction with increasing temperature was constructed (Fig. 4B). It was then simply a matter of applying the observed ${ }^{40} \mathrm{Ar} /{ }^{39} \mathrm{Ar}$ muscovite (young) component age to this curve to derive the effective maximum temperature possibly experienced by the rocks during the supposed Early Jurassic metamorphic peak.

This style of forward modelling for an Early-Late Triassic (Torlessia faunal zone) rapidly cooled muscovite exhibiting $20 \mathrm{~m} . y$. of age reduction (i.e., 225-205 Ma) after deposition implies a maximum temperature of $328-335^{\circ} \mathrm{C}$ (Fig. 4B, curve 1). Another set of numerical models was run using MacArgon, deposition now starting at $215 \mathrm{Ma}$ (mid 

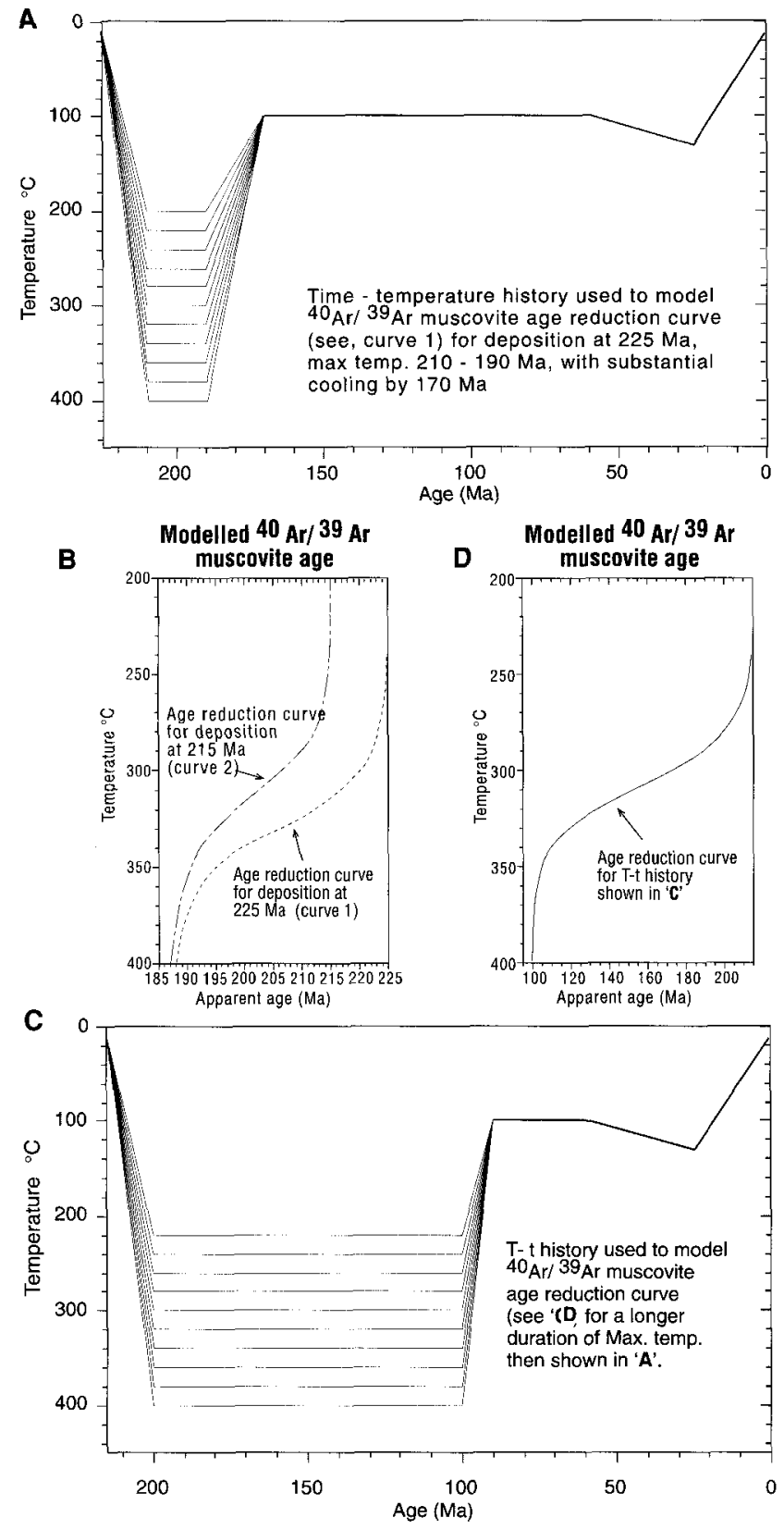

Fig. 4 Time-temperature models $(\mathrm{A}, \mathrm{C})$ run through MacArgon (Lister \& Baldwin 1996) to derive total fusion ages and hence apparent age reduction curves (B, D). These are used to estimate the maximum temperatures the rocks must have experienced if the youngest measured ${ }^{40} \mathrm{Ar} /{ }^{39} \mathrm{Ar}$ resulted from partial thermal overprinting in the Torlesse prism. In (B), curve 1 results from the total fusion ages shown for the family of T-t paths illustrated in (A). Curve 2 in (B) is generated for deposition starting at $215 \mathrm{Ma}$ with no inherited age. The age reduction curve in (D) results from the total fusion ages modelled from the T-t paths in (C). Although there may be some uncertainties about the later part of the model thermal histories, they are not of significance to the question of whether the youngest component in the measured ${ }^{40} \mathrm{Ar} /{ }^{39} \mathrm{Ar}$ muscovite ages (Adams \& Kelley 1998) are detrital or partially overprinted, as the MacArgon numerical model ages are not sensitive to temperature histories cooler than $200^{\circ} \mathrm{C}$. Diffusion parameters used for muscovite: activation energy $41.80 \mathrm{kcal} / \mathrm{mole}$; frequency factor $3.3520 \mathrm{e}-7 \mathrm{~cm}^{2} / \mathrm{s}$; activation volume $10.00 \mathrm{~cm}^{3}$; radius of diffusion domain $5.90 \mu \mathrm{m}$; type of domain - slab.
Norian). The results show that, for an observed muscovite ${ }^{40} \mathrm{Ar} /{ }^{39} \mathrm{Ar}$ age mode of $189 \pm 3 \mathrm{Ma}$ or $202 \pm 4 \mathrm{Ma}$, such as that exhibited for Norian strata (Fig. 4A, B) in the Rakaia Terrane, to be generated by partial thermal overprinting, requires heating in the prism by at least $290^{\circ} \mathrm{C}(2 \sigma$ level $)$ (Fig. 4B, curve 2). These modelled temperature estimates probably exceed the low-grade metamorphic facies conditions that the rocks have experienced. Could the young muscovite mode be generated by a different thermal history involving a longer time-scale of heating and later (Cretaceous) timing of cooling from maximum temperatures? Numerical modelling of this scenario (Fig. 4C) for mid-Norian deposition results in a different age-reduction curve (Fig. 4D) from those illustrated earlier, because of the effect of a longer duration of exposure to maximum temperature. For mid-Norian (215 Ma) deposition of rapidly cooled muscovite, the maximum temperatures required to reduce muscovite ages from $215 \mathrm{Ma}$ to $185-210 \mathrm{Ma}$ would be $265-290^{\circ} \mathrm{C}$. If the muscovite started to accumulate age before $215 \mathrm{Ma}$, higher maximum temperatures would be required to partially degas the youngest observed age component. The temperature range $265-290^{\circ} \mathrm{C}$ could have been experienced by the rocks based on the prehnitepumpellyite metamorphic mineralogy reported for the Torlesse greywacke generally in Canterbury. The question of the detrital versus partially overprinted origin of the published muscovite ${ }^{40} \mathrm{Ar} /{ }^{39} \mathrm{Ar}$ ages in the Rakaia Terrane cannot be uniquely resolved by forward modelling if cooling from maximum temperatures occurred during the mid Cretaceous. To resolve this issue, the ages need to be evaluated in relation to another low-temperature thermochronometer. The forward modelling has demonstrated, however, that the muscovite ages are not compatible with cooling from a principal metamorphic peak during the Early Jurassic.

\section{U-Pb ZIRCON AGES}

Single crystal, in some cases core and rim, SHRIMP U-Pb ages have been reported for several Rakaia Terrane samples (Ireland 1992; Adams et al. 1998). These data are proving to be of important value in establishing provenance ages for the sediments, as illustrated by Adams et al. (1998). The U$\mathrm{Pb}$ age of the youngest zircon grains is of importance to the issue being addressed here: the depositional age of the Rakaia Terrane.

In a sample (HERM2) from the Hermitage (Mt Cook), Adams et al. (1998) reported young grains with ages of 208 $\pm 6,213 \pm 3$, and $216 \pm 3 \mathrm{Ma}$ amongst 62 other dated crystals with ages ranging up to $1264 \pm 13 \mathrm{Ma}$. These three youngest crystals are Norian-Rhaetian (latest Triassic) in age, assuming no $\mathrm{Pb}$ loss, younger than the inferred pre-Norian age of the Torlessia faunal zone ascribed to the rocks at $\mathrm{Mt}$ Cook. The crystals probed are reported to have highly faceted euhedral form with distinct terminations and no rounding, and could be interpreted as first-cycle volcanic grains, but crystals with the same petrographic character are common in the sample analysed and have ages as old as $830 \pm 9 \mathrm{Ma}$ (Adams et al. 1998).

Ireland (1992) reported a U-Pb SHRIMP age of $211 \pm 5$ Ma for a zircon rim spot analysis for a sample from Aviemore in South Canterbury, probably within the Atomodesma faunal zone. This radiometric Late Triassic age is at odds with the Permian paleontological age. 


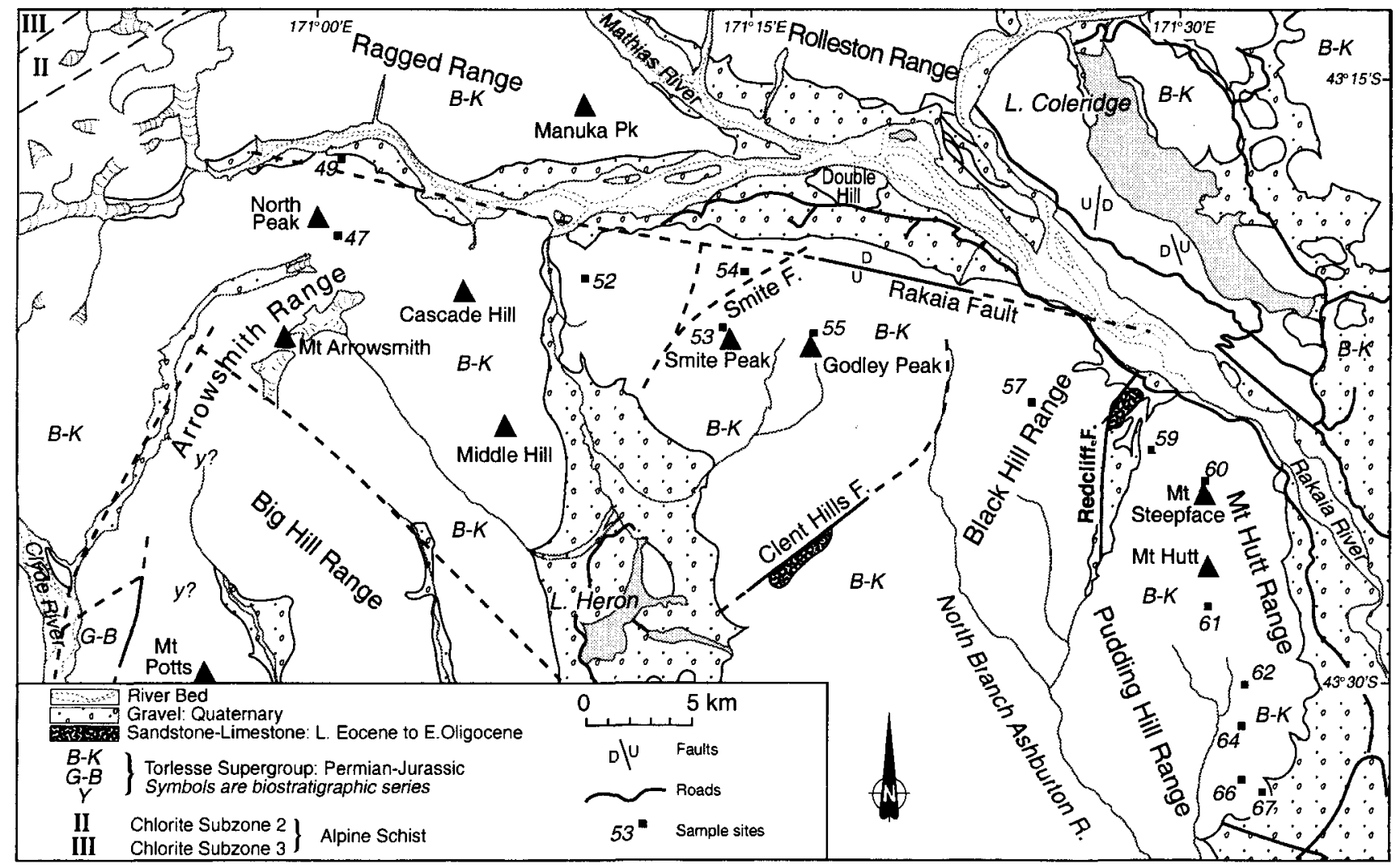

Fig. 5 Map of the Rakaia valley and associated mountains, mid Canterbury, showing sample sites for which new zircon FT ages are reported (Table 1). Map based on Gregg (1964) and Warren (1967), showing paleontologically assigned ages of the Rakaia Terrane rocks.

Lindsay et al. (1994), as noted by Mortimer (1995), reported a population of $175-190 \mathrm{Ma}$ (Early Jurassic) SHRIMP U-Pb zircon ages for a sample of Rakaia Terrane (Axial-A petrofacies) sandstone from the Kaimanawa Range in central North Island. Although this is far from an extensive dataset, reported only in an abstract, and there is always the possibility that the grain ages have been reduced through $\mathrm{Pb}$ loss, they do indicate that parts of the Rakaia Terrane may be younger than Late Triassic (Norian).

The youngest zircon crystal analysed in the Norian zone sample from Otaki (OTQ1) has a U-Pb age of $220 \pm 3 \mathrm{Ma}$ (Adams et al. 1998), an age that sits on the Carnian/Norian boundary at $220.7 \pm 4.4 \mathrm{Ma}$ (Gradstein et al. 1994). This crystal is reported to be a fragment with unidentifiable crystal form and therefore is probably not of volcanic first-cycle origin; its age probably indicates that it cooled in the source area through the $\mathrm{U}-\mathrm{Pb}$ zircon blocking temperature of $650^{\circ} \mathrm{C}$ during the Carnian-Norian (Late Triassic).

The significance of these young U-Pb zircon ages for the depositional age of the inferred Late Triassic sediments depends upon whether the grains have experienced $\mathrm{Pb}$ loss, originated from contemporaneous volcanism, or whether they were eroded from plutonic-metamorphic basement in a continental arc setting. If it is the latter, it would have required special tectonic-denudational circumstances for crystals to have cooled from $650^{\circ} \mathrm{C}$ at depth in the crust during the Late Triassic and to also have been deposited during the Late Triassic. This point is returned to below.

\section{FISSION TRACK THERMOCHRONOLOGY}

Fission track analysis applied to uranium-bearing minerals such as apatite and zircon is a low-temperature thermochronometer. The measured ages record the timing of geological events in situations where cooling through the temperature range over which the daughter product (fission tracks) typically accumulates is rapid. In many situations, however, the measured ages are apparent ages resulting from residence in a so-called partial annealing zone (PAZ), where the radiometric system has been partially open. In these situations, FT parameters of age and length are interpreted to infer the thermal history (time-temperature history) experienced by the sample host rocks. The systematics of annealing are now well known for FTs in apatite, both at laboratory and geological time-scales, and thermal histories can be interpreted and modelled routinely for the temperature range $110-50^{\circ} \mathrm{C}$ (Gleadow et al. 1986; Green et al. 1986 , 1989; Laslett et al. 1987; Duddy et al. 1988; Gallagher 1995; Gallagher et al. 1998). For zircon, the temperature range over which partial annealing occurs at geological time-scales is less precisely known, but lies within the range $210-260^{\circ} \mathrm{C}$ (Tagami et al. 1998; Brandon et al. 1998). The lowtemperature end of this range is constrained by age patterns in ultra-deep drillholes, with no indication of partial annealing at $210^{\circ} \mathrm{C}$ (Tagami et al. 1996). Coyle \& Wagner (1996) reported mean track lengths of $8.9 \pm 0.3 \mu \mathrm{m}$ (down from unannealed lengths typically of $10.4 \pm 0.4 \mu \mathrm{m}$ ) at a temperature of c. $255^{\circ} \mathrm{C}$, meaning that partial annealing starts 
Table 1 Zircon fission track data for Rakaia Terrane samples.

\begin{tabular}{|c|c|c|c|c|c|c|c|c|c|c|c|c|}
\hline \multirow[b]{2}{*}{ Sample no. } & \multicolumn{2}{|c|}{ Co-ordinate* } & \multirow{2}{*}{$\begin{array}{l}\text { No. of } \\
\text { crystals }\end{array}$} & \multicolumn{2}{|c|}{ Spontaneous } & \multicolumn{2}{|c|}{ Induced } & \multirow{2}{*}{$\begin{array}{c}\mathbf{P}\left(\chi^{2}\right) \\
\%\end{array}$} & \multirow{2}{*}{$\begin{array}{l}\rho_{\mathrm{s}} / \rho_{\mathrm{i}} \\
\pm 1 \sigma\end{array}$} & \multirow[b]{2}{*}{$\rho_{\mathrm{d}}$} & \multirow[b]{2}{*}{$\mathrm{N}_{\mathrm{d}}$} & \multirow{2}{*}{$\begin{array}{l}\text { Age (Ma) } \\
\quad \pm 1 \sigma\end{array}$} \\
\hline & $\mathrm{X}$ & $\mathrm{Y}$ & & $\rho_{\mathrm{s}}$ & $\mathrm{N}_{\mathrm{s}}$ & $\rho_{i}$ & $\mathrm{~N}_{\mathrm{i}}$ & & & & & \\
\hline $8902-69$ & 22486 & 56839 & 20 & 9.136 & 1786 & 5.033 & 984 & $<0.1$ & $2.196 \pm 0.170$ & 0.896 & 2125 & $118.3 \pm 14.1$ \\
\hline $8902-71$ & 22547 & 56785 & 20 & 12.020 & 1179 & 6.371 & 1179 & 1.1 & $1.916 \pm 0.128$ & 0.886 & 2103 & $110.9 \pm 6.1$ \\
\hline $8902-72$ & 22568 & 56752 & 12 & 10.280 & 1112 & 2.791 & 302 & 89.5 & & 0.882 & 2093 & $215.7 \pm 15.4$ \\
\hline $8902-73$ & 22554 & 56600 & 20 & 10.150 & 1791 & 3.427 & 605 & 84.4 & & 0.878 & 2082 & $173.2 \pm 9.7$ \\
\hline $8902-74$ & 22693 & 56346 & 20 & 10.970 & 2300 & 3.738 & 784 & 84.5 & & 0.873 & 2072 & $170.7 \pm 8.7$ \\
\hline $8902-75$ & 22779 & 56258 & 2 & 7.795 & 503 & 3.053 & 197 & 68.9 & & 0.965 & 4577 & $164.3 \pm 14.4$ \\
\hline $8902-133$ & 23924 & 58075 & 5 & 13.160 & 512 & 4.086 & 159 & 22.9 & & 0.785 & 1863 & $168.5 \pm 16.2$ \\
\hline $8902-134$ & 23935 & 58045 & 20 & 12.110 & 1965 & 3.907 & 634 & 8.0 & & 0.934 & 2216 & $192.6 \pm 10.5$ \\
\hline $9101-225$ & 23117 & 56051 & 11 & 10.005 & 564 & 3.654 & 206 & 82.3 & & 1.048 & 2590 & $191.0 \pm 16.5$ \\
\hline $9501-47$ & 23482 & 57639 & 20 & 11.100 & 2423 & 3.523 & 769 & 58.0 & & 0.779 & 1849 & $163.2 \pm 8.0$ \\
\hline $9501-49$ & 23491 & 57683 & 20 & 11.140 & 2590 & 3.295 & 766 & 90.4 & & 0.943 & 4473 & $211.9 \pm 10.3$ \\
\hline $9501-52$ & 23609 & 57613 & 20 & 10.620 & 1653 & 2.988 & 465 & 91.6 & & 0.786 & 1865 & $186.0 \pm 10.7$ \\
\hline $9501-53$ & 23673 & 57601 & 20 & 8.514 & 1826 & 2.462 & 528 & 87.1 & & 0.792 & 1880 & $182.4 \pm 9.9$ \\
\hline $9501-54$ & 23677 & 57628 & 20 & 10.200 & 1868 & 3.030 & 555 & 26.7 & & 0.954 & 4526 & $213.3 \pm 11.7$ \\
\hline $9501-55$ & 23714 & 51595 & 20 & 10.050 & 1593 & 2.959 & 469 & 5.3 & & 0.959 & 4552 & $216.4 \pm 12.6$ \\
\hline $9501-57$ & 23817 & 57566 & 20 & 12.010 & 1664 & 3.890 & 539 & 80.6 & & 0.904 & 2144 & $185.8 \pm 10.8$ \\
\hline $9501-59$ & 23878 & 57543 & 20 & 11.210 & 1724 & 3.818 & 587 & 47.1 & & 0.908 & 2155 & $177.7 \pm 10.0$ \\
\hline $9501-60$ & 23907 & 57546 & 20 & 9.673 & 1689 & 3.247 & 567 & 59.3 & & 9.130 & 2166 & $181.1 \pm 10.3$ \\
\hline $9501-61$ & 23907 & 57472 & 20 & 10.260 & 2074 & 3.102 & 627 & 3.6 & $3.369 \pm 0.185$ & 0.918 & 2177 & $197.8 \pm 13.0$ \\
\hline $9501-62$ & 23922 & 57442 & 20 & 11.920 & 2341 & 3.304 & 649 & 19.7 & & 0.779 & 1896 & $186.9 \pm 9.7$ \\
\hline $9501-64$ & 23926 & 57415 & 20 & 13.130 & 2205 & 3.423 & 575 & 8.6 & & 0.806 & 1912 & $199.9 \pm 13.0$ \\
\hline $9501-66$ & 23925 & 57394 & 20 & 16.990 & 4675 & 4.255 & 1171 & 99.0 & & 0.812 & 1927 & $215.3 \pm 8.6$ \\
\hline $9501-67$ & 23937 & 57387 & 20 & 8.753 & 1030 & 2.898 & 341 & 87.6 & & 0.922 & 2188 & $185.4 \pm 12.8$ \\
\hline
\end{tabular}

Track densities $(\rho)$ are $\times 10^{6}$ tracks $\mathrm{cm}^{-2}$. All analyses are by the external detector method using 0.5 for the $4 \pi / 2 \pi$ geometry correction factor. Zircon ages calculated using dosimeter glass $\mathrm{CN} 1$ and zeta-CN1 $=135.1+2.8(+1 \sigma) . \mathrm{P}\left(\chi^{2}\right)$ is the probability of obtaining $\chi^{2}$ value for $v$ degrees of freedom (where $v$ is the number of crystals -1 ) [Galbraith 1981 ]; pooled $\rho$ s/ $\rho$ i ratio is used to calculate age and uncertainty where $\mathrm{P}\left(\chi^{2}\right)>5 \%$; mean $\rho$ s/ $\rho$ i ratio is reported for samples where $\mathrm{P}\left(\chi^{2}\right)<5 \%$ and for which Central ages [Galbraith \& Green 1991 ] are calculated. $* \mathrm{X}$ and $\mathrm{Y}$ coordinate refer to New Zealand Map Series 260 (1: 50000 scale); full co-ordinate values are completed by two zeros at the end of each value listed. 
Fig. 6 Summary of zircon and apatite $(\diamond)$ ages for the Arthur's Pass transect oriented normal to the Alpine Fault. Distance shown is distance from the Alpine Fault. The lower panel is a restored crustal section showing the position of the Late Cretaceous zircon partial annealing zone (PAZ), and where it crops out at the surface $(11-25$ $\mathrm{km}$ from the Alpine Fault). This is northwest of the zircon FT ages RP1-RP6 (weighted mean $189 \pm$ $8 \mathrm{Ma}$ ), which occur at a higher structural level and have not entered the zircon PAZ, and therefore are considered to be detrital ages. Fission track data (RP samples) from Kamp et al. (1989) and Tippett \& Kamp (1993) (numbers completed by prefix 8902-). New ages shown for 8901-133 and 8901-134 are new ages reported in Table 1. Abbreviations: GO, garnetoligoclase zone schist; $\mathrm{B}$, biotite zone; CIII, chlorite 3 zone; CII, chlorite 2 zone schist.

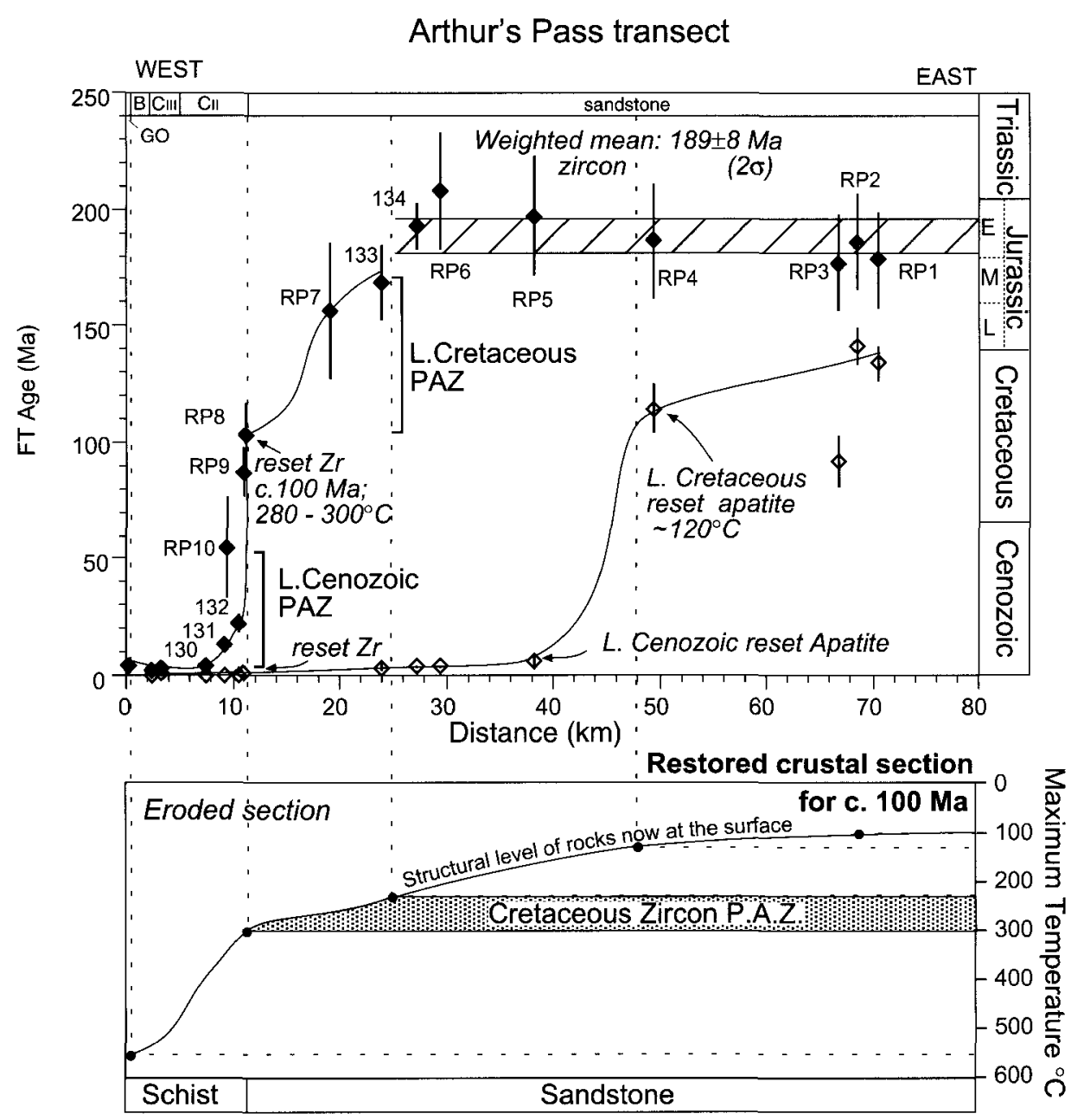

between 210 and $255^{\circ} \mathrm{C}$. The high-temperature end of the zircon PAZ for detrital sediments is considered to be c. $260^{\circ} \mathrm{C}$, based on the arguments and data summarised by Brandon et al. (1998).

In the following sections, new zircon FT ages are reported for Rakaia Terrane rocks from the Rakaia valley in mid Canterbury (Fig. 5). Apatite FT ages and mean lengths for the same samples have been published elsewhere (Kamp 1997). Previously reported zircon FT ages for Rakaia Terrane rocks in Canterbury (Kamp et al. 1989; Tippett \& Kamp 1993) are reconsidered, and some have been redated (Table 1).

\section{Experimental procedures}

Samples of sandstone basement $(2-4 \mathrm{~kg}$ ) collected from the Rakaia valley were crushed, and standard magnetic and heavy liquid techniques were used to concentrate zircon crystals. These concentrates were prepared for irradiation in the nuclear reactor at Oregon State University, USA, following the procedures outlined in Green (1985) and Kamp et al. (1989). In particular, the teflon zircon mounts were etched in $\mathrm{NaOH}: \mathrm{KOH}$ eutectic solution at $230 \pm 1{ }^{\circ} \mathrm{C}$ for $22-25 \mathrm{~h}$ to optimise the number of grains with well-etched tracks in all directions with respect to the $c$-axis. The external detector method (Gleadow 1981) has been used exclusively throughout this study. The FT ages were determined using the zeta calibration method (Hurford \& Green 1982; Green
1985). FT ages were calculated as central ages (Galbraith \& Green 1991).

\section{Fission track results and interpretations}

New analytical data are shown in Table 1, and all data including that reported previously are illustrated in Fig. 6 11. The data are considered in transects oriented normal to the Alpine Fault, as Neogene denudation centred between the fault and the Main Divide has had a profound effect upon the structure in the ages and the level of the crust exposed at the surface (Kamp \& Tippett 1993).

\section{Arthur's Pass transect}

Figure 6 combines data published by Kamp et al. (1989) and Tippett \& Kamp (1993) (see caption for full sample numbers). The ages shown for samples 133 and 134 are new determinations (Table 1). The basic interpretation of the structure in the age data has not changed from Kamp et al. (1989): with increasing proximity to the Alpine Fault, deeper levels in the crust are exposed, as reflected in the occurrence of successive partially annealed and reset FT zones and the metamorphic grade. The zircon ages within $10 \mathrm{~km}$ of the Alpine Fault in the Arthur's Pass transect comprise a zone of reset Late Cenozoic ages that date the timing (c. $5 \mathrm{Ma}$ ) of the start of denudation of the Southern Alps in that area, and a tectonically narrowed PAZ formed at ambient temperatures of $210-260^{\circ} \mathrm{C}$ between the Late Cretaceous 


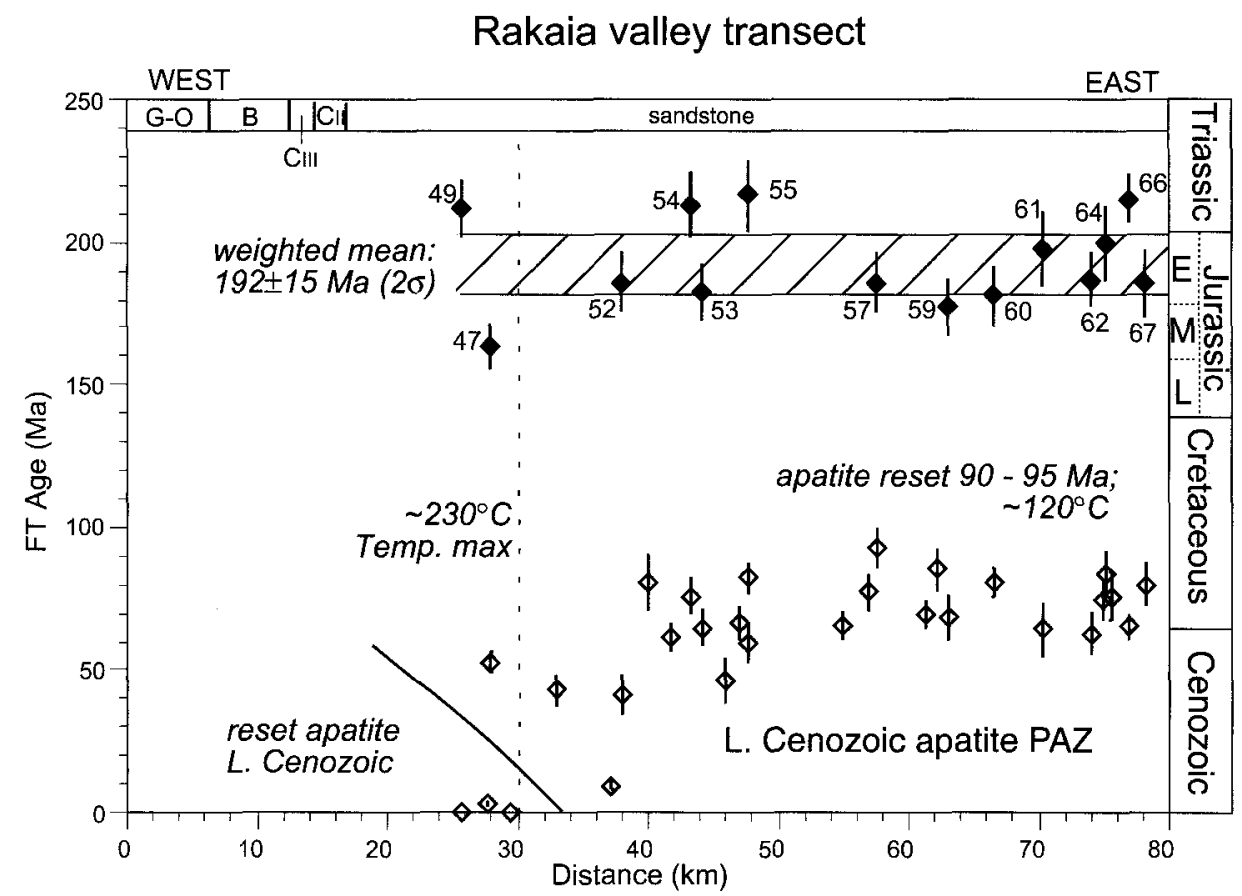

Fig. 7 Summary of zircon ( and apatite $(\diamond)$ FT ages for a transect through the Rakaia valley orthogonal to the Alpine Fault and with increasing distance eastward from it. The weighted mean zircon FT age is $192 \pm 15 \mathrm{Ma}$ (Early Jurassic). The apatite FT ages for these samples are reported in Kamp (1997). The sample numbers $47-67$ are completed by the prefix 9501-. and $5 \mathrm{Ma}$. At $11 \mathrm{~km}$ from the fault, there is a distinct inflection point (age: $103 \pm 13 \mathrm{Ma}$ ) marking the top of a middle Cretaceous reset zone, indicating the start of an earlier and significant denudation phase. Between 11 and $25 \mathrm{~km}$ east of the Alpine Fault is the related zircon PAZ, fossilised by the c. $100 \mathrm{Ma}$ cooling event. East of $25 \mathrm{~km}$ from the Alpine Fault, there is a plateau of zircon FT ages, which have an overall weighted mean age of $189 \pm 8 \mathrm{Ma}$ ( $2 \sigma$ error) (Early Jurassic). The consistency in the mean ages of these samples suggests that they are reset ages, either through cooling in the source area, or through heating (to c. $260^{\circ} \mathrm{C}$ ) and subsequent cooling (from c. $189 \pm 8 \mathrm{Ma}$ ) in the Torlesse prism.

The key issue to help solve questions surrounding the muscovite ${ }^{40} \mathrm{Ar} /{ }^{39} \mathrm{Ar}$ ages younger than the paleontological age assignments is whether to interpret the zircon FT ages between 25 and $75 \mathrm{~km}$ east of the Alpine Fault as never having entered a PAZ in the prism (option 1), or as having been heavily partially annealed or reset in the prism (option 2 ). In option 1 , there would only have been two partial annealing/reset zones develop in the Torlesse prism, including the Alpine Schist and greywacke sections. These PAZs are shown in Fig. 6. Option 1 is the preferred interpretation of the structure in the FT data. It implies that the zircon ages $25-75 \mathrm{~km}$ from the Alpine Fault are detrital ages that have not been reduced by partial annealing in the prism, reflect the timing of cooling in the source area, and provide maximum stratigraphic ages (Early Jurassic) for the Torlesse host rocks. Constraints on the amount of postdepositional heating and cooling experienced by these rocks are provided by the occurrence of a fossil Late Cretaceous PAZ structurally below them and cropping out to the west, and by the location of the Late Cretaceous apatite reset inflection point, as shown in the restored crustal section in Fig. 6. One reason option 1 is favoured is that it implies a reasonable maximum temperature $\left(\right.$ c. $260^{\circ} \mathrm{C}$ ) for the greywacke/schist boundary (Fig. 6).
Option 2 would require there to have been three zircon PAZs in the Torlesse prism. The oldest one, presumably fossilised in the Early Jurassic, has not been located. The Rakaia Terrane rocks now at the surface in Canterbury in this option would have experienced maximum paleotemperatures of c. $260^{\circ} \mathrm{C}$ at least, corresponding to the base of a zircon PAZ. It follows that the temperature at the greywacke/schist (sandstone/chlorite II) boundary would have been between 310 and $360^{\circ} \mathrm{C}$, normally ascribed to rocks well within the chlorite zone, resulting from $50-120^{\circ} \mathrm{C}$ of Early Jurassic cooling as judged by the difference between the total amount of cooling for samples 134 and RP1-RP6 for option 1 versus option 2. The maximum paleotemperatures for the various zones within the Alpine Schist would also need to be higher by $50-120^{\circ} \mathrm{C}$ under option 2 compared with those shown in Fig. 6.

An independent estimate of maximum temperature in the greywacke section is given by vitrinite reflectance data for the Arthur's Pass transect reported by Green et al. (1996). East of the $25 \mathrm{~km}$ mark, measured VR values are $\leq 3.0 \%$ $\mathrm{Ro}_{\max }$. Modelling of these data using the Burnham \& Sweeney (1989) kinetic model (equation 2) shows that a VR value of $3.0 \%$ corresponds to a maximum temperature of $225^{\circ} \mathrm{C}$ for durations of heating of $10 \mathrm{~m} . \mathrm{y}$. or longer. This result is consistent with option 1 interpretation of the zircon FT data in which the rocks $25-75 \mathrm{~km}$ from the Alpine Fault would not have been partially annealed in the prism. If the zircon FT ages are not reset, then the young component of muscovite ${ }^{40} \mathrm{Ar} /{ }^{39} \mathrm{Ar}$ ages will not be partially disturbed and therefore will reflect detrital ages as well.

\section{Rakaia valley transect}

New zircon FT ages for rocks from the southern side of the Rakaia valley (Fig. 5) are illustrated in Fig. 7. The overall weighted mean age (excluding 9501-47) is $192 \pm 15(2 \sigma)$ Ma (Early Jurassic). All of these ages, except that for 950147 , which is marginally younger than the others, are 
considered to be detrital ages, not influenced by partial annealing in the Torlesse prism. The base of the late Cenozoic apatite PAZ coincides with a maximum temperature of c. $230^{\circ} \mathrm{C}$, being the temperature at the base of two apatite PAZs, as for the Arthur's Pass transect. The base of the late Cretaceous apatite PAZ that contributes 110 $\pm 10^{\circ} \mathrm{C}$ to the maximum temperature has been eroded during the late Cenozoic. Forward modelling of the older apatite ages with long lengths (Kamp unpubl. data) shows that they were reset at c. 90-95 Ma. The mean zircon FT age in sample 9501-47 may be partially annealed, as it is distinctly younger than the other zircon ages. This would place the top of the Late Cretaceous PAZ a comparable distance east of the greywacke/schist boundary in the Rakaia valley, as for the Arthur's Pass transect.

Figure 8 illustrates the individual zircon FT grain ages across the 13 new zircon samples as a probability-density distribution and in a radial plot. Most of the grains conform to a unimodal distribution, but with a tail to older ages. Excluding the small percentage of older grains, the majority of single-grain ages are most simply explained as representing natural variation around a uniform modal age of c. $189 \mathrm{Ma}$. This age is less than the overall weighted mean age for the 13 samples because the mode excludes the older grains that are nevertheless anticipated in a detrital population. The conclusion is drawn that the 189 Ma peak age reflects the setting of the FT clock in the Torlesse source area as the source rocks cooled through the temperature range $260-210^{\circ} \mathrm{C}$, predating deposition in the Torlesse prism.

\section{Waitaki valley transect}

Figure 9 illustrates FT data for the Waitaki transect in North Otago. Several of the zircon FT ages are new, the irradiated grain mounts having been recounted after ages were initially reported by Tippett \& Kamp (1993), and these are recorded in Table 1.

The weighted mean age of the zircon FT ages for sites east of $60 \mathrm{~km}$ from the Alpine Fault is $182 \pm 12(2 \sigma) \mathrm{Ma}$, an age range within the Early-Middle Jurassic. Several features suggest, however, that the zircon FT ages in this group may have been partially annealed in the Torlesse prism. The sample mean ages have a wide age range. The single-grain ages illustrated in a probability-density plot and radial plot (Fig. 10) also show a much wider distribution and a modal peak age ( $173 \mathrm{Ma}$ ) significantly younger than for the Rakaia valley dataset. In addition, there are fewer old grains and the maximum age is younger. These features about the dataset could arise through partial annealing. Another feature is that the base of the Late Cretaceous annealing zone 30 $\mathrm{km}$ east of the Alpine Fault corresponds to the chlorite IIIIV boundary, whereas, in the Arthur's Pass transect, it coincides with the greywacke/chlorite II boundary. What appears to be a single Late Cretaceous zircon PAZ is probably a composite feature, there having been an Early Cretaceous cooling phase before a more significant cooling phase from c. $100 \mathrm{Ma}$. If this is so, the modal age of 173 Ma does not constrain the depositional age of the sediments, which will be older. This transect is oriented parallel to the Otago Schist arch and immediately north of it. The higher maximum temperatures associated with the greywacke in this transect compared with Rakaia/Arthur's Pass, and the greater amounts of Cretaceous exhumation, probably reflect deeper particle paths followed in the Torlesse accretionary
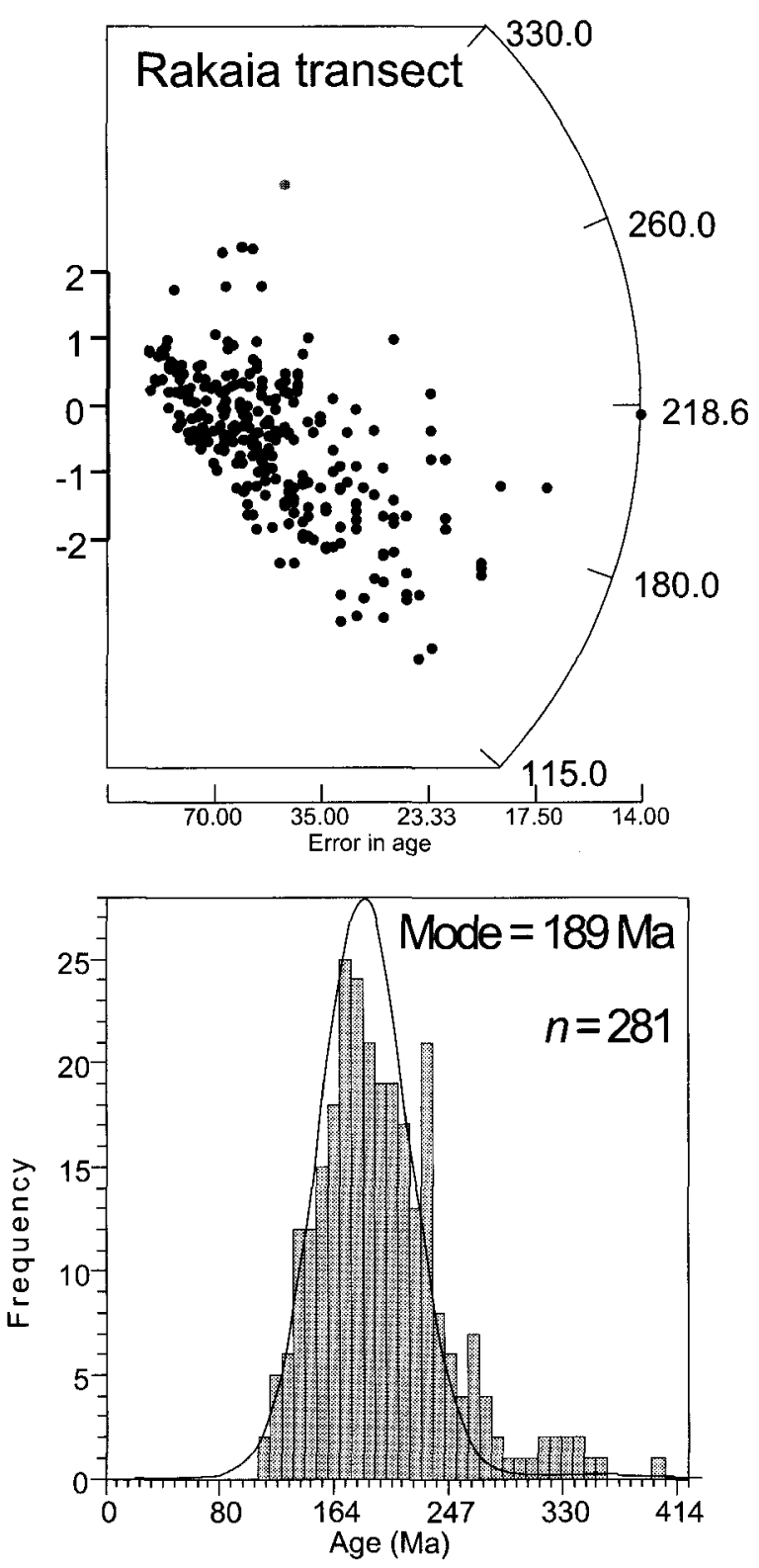

Fig. 8 Radial plot (above) and probability-density function (below) showing the individual zircon FT ages for 13 samples 9501-49 to 9501-67. The data mostly conform to a single distribution with a peak of $189 \mathrm{Ma}$, but there is a tail of older ages as well.

prism in more southern compared with more northern parts of the Rakaia succession.

\section{Zircon FT ages at the Hermitage, Mt Cook}

The FT data available for the Mt Cook region (Kamp et al. 1989; Tippett \& Kamp 1993) (Table 1) are illustrated in Fig. 11. The structure in the zircon FT ages with distance east of the Alpine Fault is not expressed as clearly as for transects to the north and south. This is probably caused by Late Cenozoic faulting (Cox \& Findlay 1995). Nevertheless, comparatively old ages (Late Triassic) are derived from greywacke between the terminus of the Hooker Glacier and the Hermitage (sample $\mathrm{He} 1$ ), also the site of ${ }^{40} \mathrm{Ar} /{ }^{39} \mathrm{Ar}$ muscovite sample HERM5 (Adams \& Kelley 1998) and 


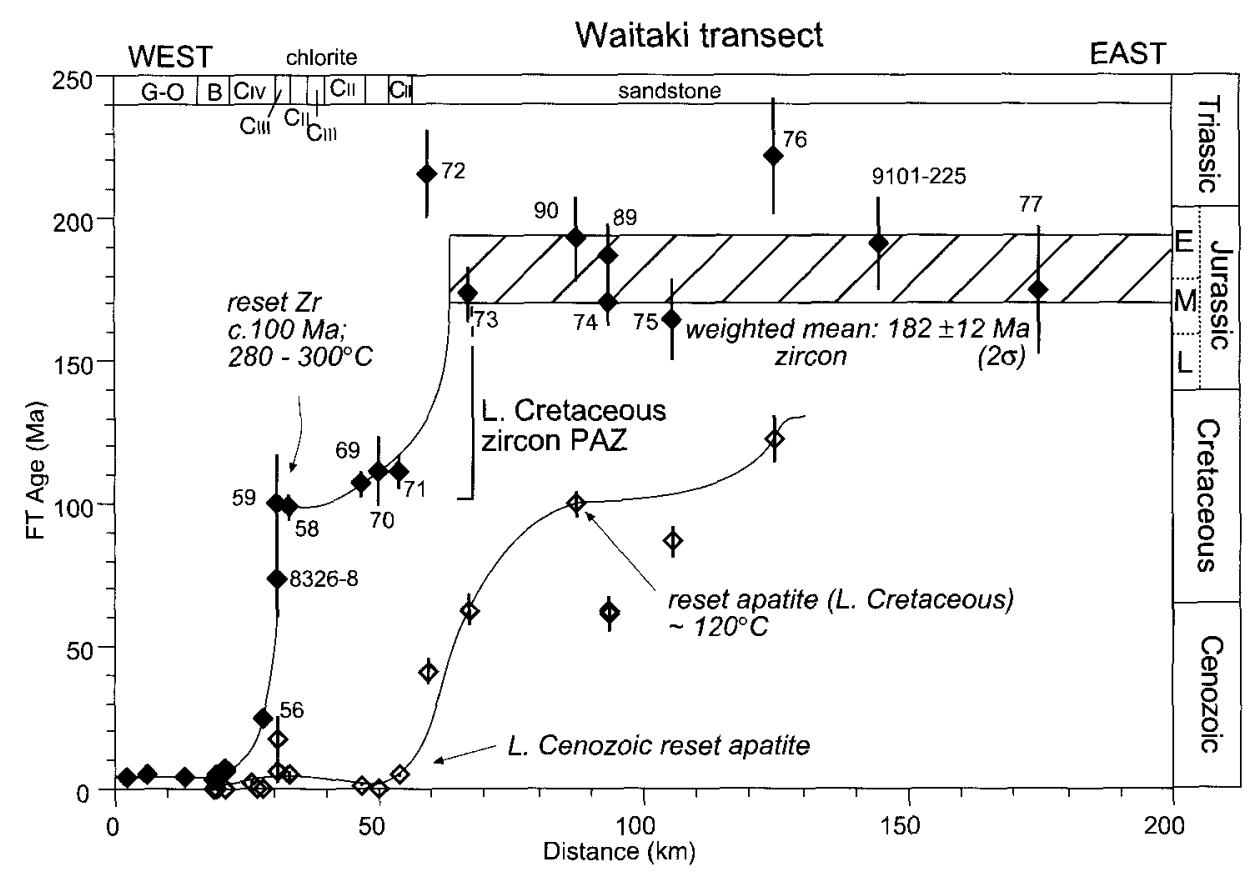

Fig. 9 Summary of zircon ( and apatite $(\diamond)$ FT ages for a transect through the Waitaki valley. Samples identified by two digits are completed by 8902 -. Zircon FT data from Kamp et al. (1989) and Tippett \& Kamp (1993), except for samples 69, 71, $72,73,74,75$ (redetermined here, Table 1) and 9101-225 (new age, Table 1). See text for interpretation of zircon FT ages.

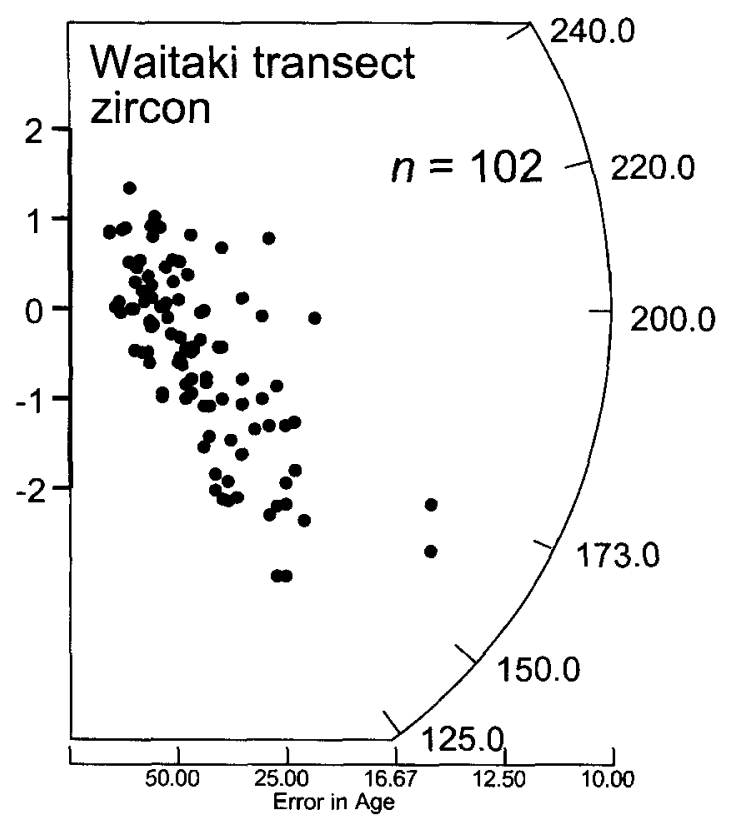

Fig. 10 Radial plot (above) and probability-density function (below) showing the individual zircon FT ages for samples 72-89 and 9101-225 (Fig. 9). See text for interpretation.

U-Pb SHRIMP sample HERM2 (Adams et al. 1998). The Late Cretaceous zircon PAZ is represented by samples 84 86. It runs into the Late Cenozoic PAZ a short distance to the west. Importantly for this discussion, the base of the Late Cretaceous PAZ coincides with the greywacke/schist (Chlorite II zone) boundary, as in the Arthur's Pass transect. The section between samples 87 and $\mathrm{He} 1$ can therefore confidently be interpreted by reference to the zircon FT patterns in Arthur's Pass and Rakaia valley transects not to have been heated to within a zircon PAZ in the Torlesse prism. This has significance for interpretation of the young ${ }^{40} \mathrm{Ar} /{ }^{39} \mathrm{Ar}$ ages from Torlessia zone sequences.

\section{DISCUSSION}

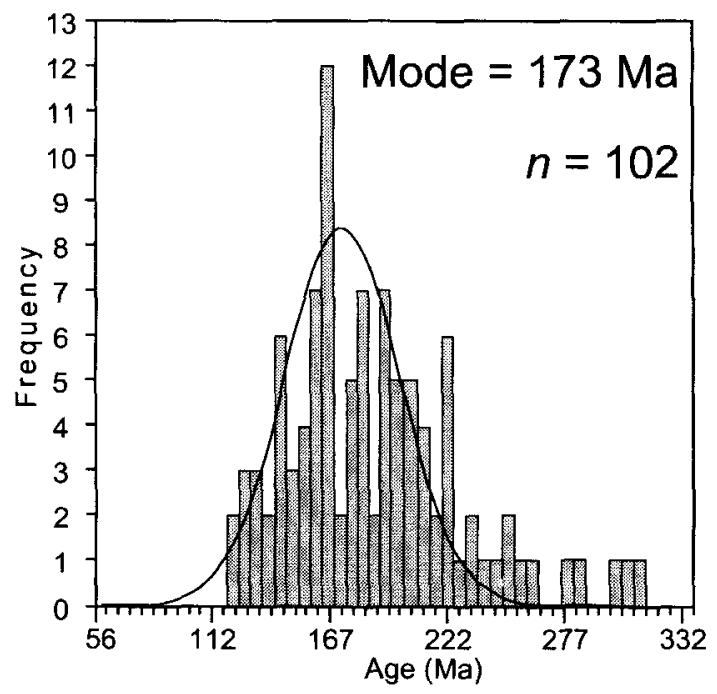

Possible Jurassic depositional age for part of Rakaia Terrane in mid Canterbury

An objective of this paper has been to test the paleontologically assigned Late Permian to Late Triassic age of the Rakaia Terrane against radiometric ages of its terrigenous components. This has arisen because a few $\mathrm{U}-\mathrm{Pb}$ zircon SHRIMP ages have been reported that appear to be younger than the conventional faunal ages, a percentage of muscovite ${ }^{40} \mathrm{Ar} /{ }^{39} \mathrm{Ar}$ ages are also younger than the fossil ages, and so too are the majority of the published and new zircon FT ages. Because the $\mathrm{U}-\mathrm{Pb}$ clock in zircon is set at high temperatures, there may be a considerable lag between the time of cooling through the blocking temperature in the source area, except for volcanically derived crystals, and incorporation in the prism. The problem with lower temperature thermochronometers is that, while their clock starts later in the denudational phase in the source area, 
Fig. 11 Summary of zircon and apatite FT ages for a transect through the Mt Cook region orthogonal to the Alpine Fault and with increasing distance eastward from it. Data from Kamp et al. (1989) and Tippett \& Kamp (1993). Sample numbers completed by prefix $8902-$.

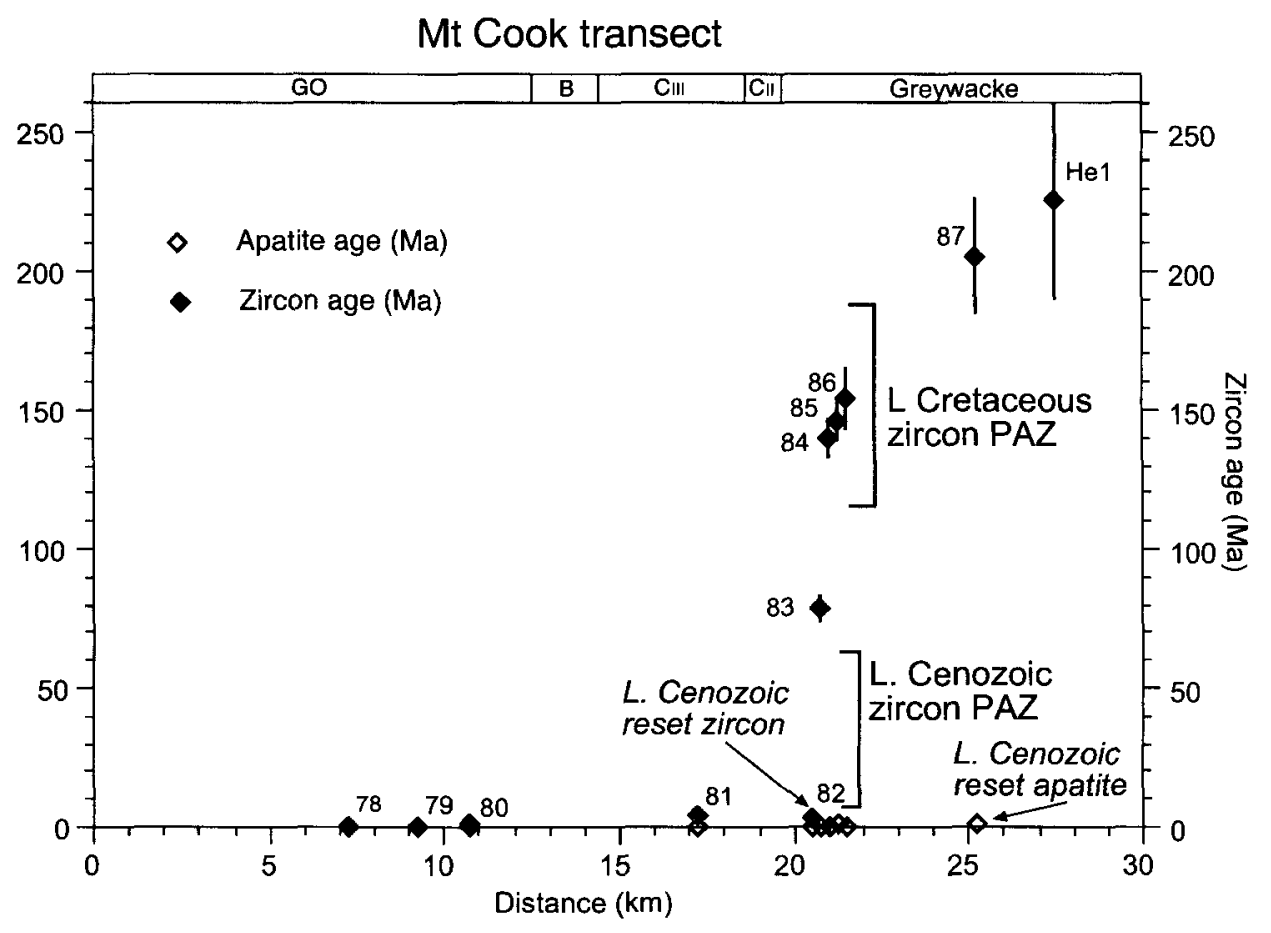

accumulated age may subsequently be partially reduced as a result of thermal overprinting in the prism arising from burial.

This paper has established the mean age and error of the youngest component in published ${ }^{40} \mathrm{Ar} /{ }^{39} \mathrm{Ar}$ ages in the various faunal zones in the Rakaia Terrane. Forward modelling using MacArgon software has demonstrated that these young component ages cannot have originated as a result of a principal metamorphic event at 210-190 Ma, as envisaged in earlier work. This modelling cannot, however, preclude the young ages as arising from age reduction due to prolonged residence at $265-290^{\circ} \mathrm{C}$ with cooling at c. $100 \mathrm{Ma}$.

The structure in published and new FT ages for rocks from east-west transects through Arthur's Pass, the Rakaia valley, and the Mt Cook region show that zircon FT ages for host rocks $25-80 \mathrm{~km}$ east of the Alpine Fault have probably not been heated to within a zircon PAZ. Consequently, these ages are interpreted as detrital ages reflecting the accumulation of tracks since cooling through $260-210^{\circ} \mathrm{C}$ in the source area, and provide maximum estimates on the depositional age of rocks within the Torlesse prism. The best estimate on this age comes from new data for rocks from the Rakaia valley, which contain a peak age of $189 \mathrm{Ma}$, corresponding to the Early Jurassic. Because the zircon FT radiometric system is a lower temperature thermochronometer than ${ }^{40} \mathrm{Ar} /{ }^{39} \mathrm{Ar}$ on muscovite, and it has been argued that the zircon FT ages in the Arthur's Pass, Rakaia, and Mt Cook transects have not been partially annealed in the prism, the Early Jurassic component of muscovite ages identified above (Fig. 3) must also be detrital ages. The youngest component in the ${ }^{40} \mathrm{Ar} /{ }^{39} \mathrm{Ar}$ biotite ages from Norian rocks in Canterbury has an age of $196 \pm 7 \mathrm{Ma}$ (Fig. 3E).

A message of this paper is that parts of the Rakaia Terrane, especially in mid Canterbury, possibly accumulated during the Jurassic. While some of the published muscovite ${ }^{40} \mathrm{Ar} /{ }^{39} \mathrm{Ar}$ ages are reported for localities in the Canterbury and Wellington areas that contain Monotis (Norian), and seem to contain a detrital Early Jurassic component of grains (Fig. 3), none of the FT samples with Early Jurassic ages were collected from beds containing Monotis or other agediagnostic taxa. More extensive application of radiometric dating methods to samples from fossil localities will help constrain numerical depositional ages for the Rakaia Terrane.

\section{Late Cretaceous uplift and erosion of Rakaia Terrane}

An interpretation that has buttressed the Late Permian to Late Triassic age assignment of the Rakaia rocks has been the notion of an Early Jurassic principal metamorphic event in the older Torlesse rocks including Otago Schist. This has largely arisen from interpretation of extensive sets of wholerock $\mathrm{K}-\mathrm{Ar}$ and $\mathrm{Rb}-\mathrm{Sr}$ ages reported for Otago Schist and Torlesse Complex (e.g., Adams et al. 1985, 1998; Adams \& Robinson 1993; Adams \& Graham 1996). The K-Ar ages (190-200 Ma) for the lowest grade rocks (phyllites in North Otago) were assumed to be reset ages recording postmetamorphic cooling (Adams et al. 1985), the younger KAr ages for progressively higher grade rocks in Otago Schist recording a protracted Jurassic-Cretaceous passage through the blocking temperature. This has supported a Late Permian to Late Triassic age for the Rakaia Terrane as the sediments had to be deposited before they could be metamorphosed. Little et al. (1999) showed that the Jurassic to mid Cretaceous whole-rock K-Ar ages on Otago Schist are a combination of provenance and partially overprinted ages, the latter originating within a partial Ar retention zone. It has also been argued that most of the extensive set of K-Ar wholerock ages reported for the Torlesse Complex in the Wellington region (Adams \& Graham 1996) are better interpreted as either provenance ages or partial Ar retention ages, with only the youngest (Cretaceous) ages being reset (Kamp 2000).

If the metamorphic peak and subsequent cooling did not start around $190 \mathrm{Ma}$, when did the Rakaia Terrane first undergo cooling and exhumation suggestive of the 
development of steady state conditions in the accretionary wedge? Little et al. (1999) proposed regional metamorphism at $170-180 \mathrm{Ma}$, followed by Early Cretaceous ( $135 \pm 5 \mathrm{Ma}$ ) timing for the start of cooling in the Otago Schist based on ${ }^{40} \mathrm{Ar} /{ }^{39} \mathrm{Ar}$ ages on muscovite. As noted above, Early Cretaceous cooling may have affected the rocks in the Waitaki valley, immediately north of the Otago Schist belt, probably to a minor extent. Zircon FT ages show that across Canterbury the first significant cooling of the Rakaia Terrane, most probably achieved by denudation, occurred from c. 100 $\mathrm{Ma}$. This is the age of an inflection point in zircon FT age profiles in transects at Waitaki (Fig. 9), Arthur's Pass (Fig. 6), and Lewis Pass (Tippett \& Kamp 1993; Kamp unpubl. data). This cooling phase seems to have affected Rakaia rocks simultaneously over the whole of Canterbury. It involved c. $100-125^{\circ} \mathrm{C}$ of cooling, which, for a geothermal gradient of $25^{\circ} \mathrm{C} / \mathrm{km}$, would amount to $4-5 \mathrm{~km}$ of denudation. This is estimated from the erosion of section containing an apatite PAZ during the Late Cretaceous.

The c. $100 \mathrm{Ma}$ age of the start of widespread cooling in Canterbury coincides with the start of active continental rifting in Westland, as evidenced by the age of lower parts of the Ohika Group and Hawks Crag Breccia (Nathan et al. 1986). However, at that time, the Rakaia Terrane was distant from Westland, and subduction still dominated eastern New Zealand (Mazengarb \& Harris 1994; Kamp 1999, 2000). It is envisaged that the Rakaia Terrane at that time lay within the forearc region, and that the phase of denudation starting at c. $100 \mathrm{Ma}$ resulted from continuing accretion at the toe of the wedge and self-similar growth of the prism (e.g., Dahlen 1990).

\section{Reconstructed thermal history and implications}

If the ${ }^{40} \mathrm{Ar} /{ }^{39} \mathrm{Ar}$ and FT ages are indeed detrital ages reflecting cooling of basement at different temperatures within the source area, these data can be used to reconstruct elements of the thermal history of the source area for the Torlesse sediments. Figure 12 illustrates a possible thermal history for sedimentary rocks in the Rakaia Terrane using the available thermochronological data. The rate of cooling in the source area is constrained by the young mode $(220 \pm$ $10 \mathrm{Ma}$ ) of zircon SHRIMP U-Pb ages for the Rakaia sediments (Adams et al. 1998), the young mode of muscovite ${ }^{40} \mathrm{Ar} /{ }^{39} \mathrm{Ar}(200 \pm 10 \mathrm{Ma}$; Fig. $3 \mathrm{~A}, \mathrm{~B}, \mathrm{C})$ and biotite ages (196 \pm 10 Ma; Fig. 3E) (Adams \& Kelley 1998), and the peak in the zircon FT ages (185-195 Ma) (Fig. 6-8). These age ranges are in the correct order based on the closure temperatures for the respective thermochronological systems anticipated in basement that is cooling rapidly. The zircon FT ages in particular constrain deposition in the Torlesse prism of the rocks exposed in the Arthur's Pass-Rakaia valley-Mt Cook area to be no older than c. $185 \mathrm{Ma}$ (late Early Jurassic). The actual depositional age of the rocks in this mid-Canterbury area may be younger, and will have varied from place to place. The termination of deposition of the deep-water beds sampled in this part of the prism had occurred by the Late Jurassic, when shallow marine to nonmarine sediments accumulated in the area (Wakaepa and Clent Hills; Oliver et al. 1982; MacKinnon 1983) on top of the accretionary prisms. The ${ }^{40} \mathrm{Ar} /{ }^{39} \mathrm{Ar}$ and FT thermochronological data relate to the greywacke east of the Main Divide, as the schistose rocks do not retain Mesozoic ${ }^{40} \mathrm{Ar} /$ ${ }^{39} \mathrm{Ar}$ and FT ages. It is assumed that marine deposition in

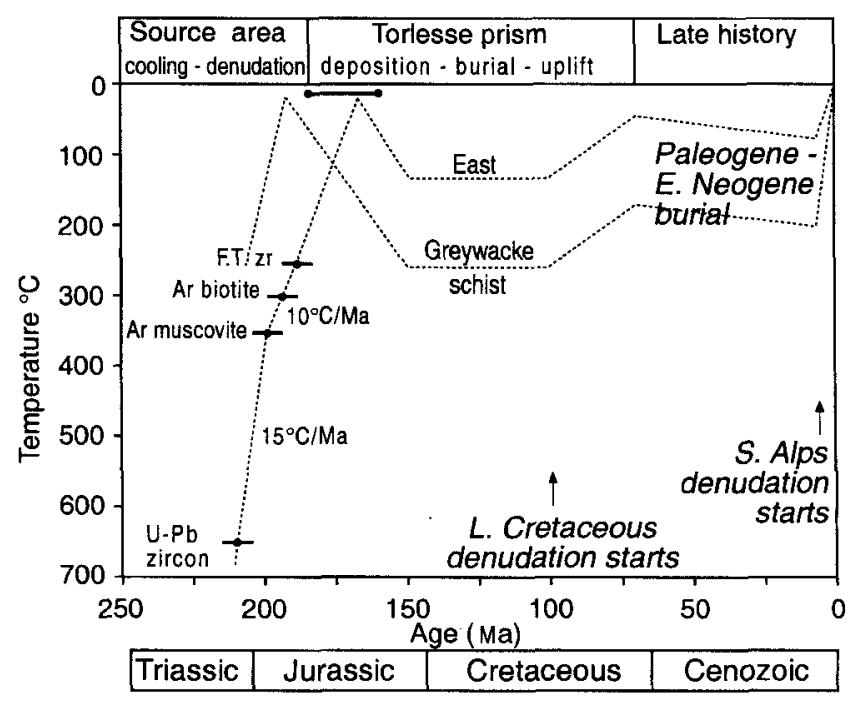

Fig. 12 Reconstructed time-temperature paths for different parts of the Rakaia Terrane in mid Canterbury based on the argument that the young component in the ${ }^{40} \mathrm{Ar} /{ }^{39} \mathrm{Ar}$ muscovite and biotite ages and the bulk of the zircon FT ages are detrital. The late part of the T-t history is constrained by cover stratigraphy, apatite FT ages in the greywacke, and zircon FT ages in the Alpine Schist. The muscovite, biotite, and zircon ages only constrain the T-t path for greywacke (attributed to the eastern foothills in mid Canterbury). There are no specific constraints on the depositional age of the greywacke (in the text it is argued that this occurred between 185 and $160 \mathrm{Ma}$ ), with burial possibly continuing until $150 \mathrm{Ma}$ (accounting for $5-6 \mathrm{~km}$ minimum of greywacke section eroded). The time-temperature paths shown reflect the particle paths taken by the sample host rocks through the Torlesse prism.

the Torlesse prism had ended by c. $150 \mathrm{Ma}$, was replaced by the accumulation of thin marginal to nonmarine beds (e.g., Clent Hills Group), and that maximum temperatures were experienced by the rocks until c. $100 \mathrm{Ma}$, for which FT data from localities in Canterbury between Late Hawea (Fig. 6 and 9) and Lewis Pass show the start of a marked cooling phase. This phase of cooling, probably achieved by denudation, had ended by $70 \mathrm{Ma}$, based on modelling of apatite FT data for the Rakaia valley (Kamp unpubl.). Late Cretaceous-Miocene sediment accumulation as part of the New Zealand-wide marine transgression probably resulted in c. $30^{\circ} \mathrm{C}$ of heating (1-1.5 km of sediment accumulation and burial) (Fig. 12) in the vicinity of the Southern Alps (Kamp 1997), and was followed by marked PliocenePleistocene cooling via denudation as the Southern Alps formed and the Torlesse complex was finally exhumed (Kamp et al. 1989; Kamp \& Tippett 1993).

The Late Triassic to Early Jurassic cooling path shown in Fig. 12 applies to greywacke in mid Canterbury and does not include Otago Schist. A feature is the rate of cooling inferred for the source area $\left(15^{\circ} \mathrm{C} / \mathrm{m}\right.$.y., c. $220-200 \mathrm{Ma}$; $10^{\circ} \mathrm{C} / \mathrm{m}$.y., c. $200-190 \mathrm{Ma}$ ). This is an order of magnitude less than for the Pleistocene rate of late Cenozoic cooling of Alpine Schist in the Southern Alps (Kamp et al. 1989), but nevertheless very rapid and indicative of a convergent margin setting, considered to be the type of margin that sourced the older Torlesse sediments (MacKinnon 1983). The relative uniformity in the sandstone petrography of the Rakaia Terrane (MacKinnon 1983), the volume of sediment that accumulated, and the relatively brief interval of sediment 
accumulation and burial represented by rocks at the surface in mid Canterbury (185-150 Ma) are consistent with rapid rates of exhumation in a convergent margin source area.

The Rakaia Terrane rocks in South Canterbury (Waitaki) are considered to contain a partially overprinted zircon FT signal resulting from heating above $210^{\circ} \mathrm{C}$ in the Torlesse prism, and therefore represent a deeper structural level than the sandstone beds exposed over much of mid Canterbury. Consequently, the deposition of the beds in South Canterbury may have predated the beds in mid Canterbury, and they will have followed a deeper particle path in the accretionary prism. The Permian (261 $\pm 2 \mathrm{Ma}$; Fig. 3D) ${ }^{40} \mathrm{Ar} /{ }^{39} \mathrm{Ar}$ muscovite age of the youngest component in the sample analysed from Aviemore (Adams \& Kelley 1998) would suggest that the sediments are older than beds at Mt Cook, but not necessarily of Permian depositional age. The rate of cooling and exhumation in the source area may have accelerated through the Triassic to Early Jurassic, implying a longer lag time between cooling through $350^{\circ} \mathrm{C}$ at depth in the crust and appearance at the surface before entry into the sedimentary system for the sediments in South Canterbury compared with mid Canterbury. It is also possible that the youngest ${ }^{40} \mathrm{Ar} /{ }^{39} \mathrm{Ar}$ mica and $\mathrm{U}-\mathrm{Pb}$ zircon ages in older parts of the Rakaia Terrane were derived from partial retention zones for these radiometric systems, the measured ages being apparent ages somewhat older than the actual age of cooling/denudation that led to sediment production. This can be thought of as the effect of inversion by erosion of partial retention zones in the crust of the source area. Another possible interpretation is that young mica ${ }^{40} \mathrm{Ar} /{ }^{39} \mathrm{Ar}$ ages and $\mathrm{U}-\mathrm{Pb}$ zircon ages in the older Rakaia Terrane beds (e.g., Aviemore sample) may reflect high-level magmatic cooling of plutons in the source area crust that predated by millions to tens of millions of years the regional cooling via denudation that sourced sediments to the South Canterbury part of the Torlesse prism. The effect of either or both the erosion of partial retention zones and magmatic cooling in the source area would be to reduce the time lag between sedimentation of Rakaia sequences in South Canterbury versus mid Canterbury. For these reasons, Permian ${ }^{40} \mathrm{Ar} /{ }^{39} \mathrm{Ar}$ ages on muscovite from Torlesse rocks in South Canterbury do not necessarily indicate Permian depositional ages of Rakaia sediments.

A feature of the thermal history portrayed in Fig. 12 is that there has been cooling of c. $120^{\circ} \mathrm{C}$ by erosion of basement sandstone from the foothills in the vicinity of the Rakaia valley (Fig. 7) (Kamp 1997). This Late Cretaceous and late Cenozoic erosion, amounting to $5-6 \mathrm{~km}$ of erosion for a geothermal gradient of $20-25^{\circ} \mathrm{C} / \mathrm{km}$ (Kamp 1997), must have been preceded by sediment accumulation. Whether this former section was Early-Middle Jurassic in age, as inferred for the rocks currently exposed, or older or younger, depends on the structural model envisaged for the Torlesse (layercake stratigraphy implies younger sediments; accretionary prism with understuffing would imply similar or older-aged sediments). Nevertheless, considerable section has been eroded, and this factor needs to be considered in discussions about the age and thermal history of the Torlesse rocks.

\section{Torlesse Complex: critical wedge concept and its implications}

Application of the terrane concept, formulated in North America during the late 1970s, has, during the past 25 years, helped advance our understanding of the origin and evolution of New Zealand basement generally, and the Torlesse Complex in particular. The terrane concept emphasises (terrane) boundaries and differences in the composition, structure, and geological history of adjacent blocks, and seeks to explain these by origins in exotic places and subsequent amalgamation. While it is helpful to subdivide the Torlesse into a series of belts or subterranes, it is probably not helpful to imply that these are separate tectonostratigraphic terranes, as it may mask their origin as one or more accretionary wedges, the formation of which may be closely related in time and space. I ask therefore, is the terrane concept the most useful paradigm to move understanding about Torlesse Mesozoic geology forward during the next 25 years?

A new framework for investigation is provided by the concept and theory of critical wedges (e.g., Chapple 1978; Davis et al. 1983; Dahlen 1990). This concept differs in that a focus is on tectonic processes in the subduction prism, the dynamics of a submarine accretionary wedge and emergent fold-thrust belt, driving forces, thermal state, fluid pressures, particle paths, and feedback between phases of deposition, deformation and erosion. It also differs from the terrane concept in emphasising the unity between different structural elements in a complex, and geological processes at convergent margins, rather than differences between elements. Thorough application of critical wedge concepts to the Torlesse Complex will require acquisition of new types of data, with important roles for structural analysis, rock mechanics, fluid-rock interactions, paleontology, and thermochronology.

The Torlesse Complex is a prototypical fossil accretionary complex ranking in all respects with other circum-Pacific examples such as the Franciscan Complex in California and the Shimanto Belt in Japan. Its disposition to investigation as a critical wedge arises from (1) its duration as an active orogen (Triassic-Late Cretaceous), (2) its differentiation into a number of belts (Bradshaw et al. 1981; Mortimer 1995; Kamp 2000), possibly reflecting wedge dynamics, and (3) the substantial exhumation of its inboard parts (Otago-Marlborough Schist), indicating achievement of steady-state conditions. In addition, the termination of subduction at c. $85 \mathrm{Ma}$ was marked by subsidence with preservation through burial of the outer parts of the prism (Raukumara); Cenozoic deformation has structurally overprinted much of the complex, but at the same time has exhumed and exposed it.

A significant unknown is the time when the Torlesse accretionary wedge first formed. This may differ from the stratigraphic age of the oldest sediments if they accumulated as a submarine fan distant from the trench setting where the sediments started to be accreted. The data presented here suggest that at least parts of the Rakaia Terrane are Jurassic in age, but it is likely that the sediments in older parts of the complex (e.g., Haast Schist) are Triassic (Fig. 3). It is suggested that imbrication of the wedge in the vicinity of the New Zealand sector of the Eastern Gondwanaland margin was underway by Middle-Late Jurassic. The Upper Jurassic nonmarine beds in mid Canterbury (Clent Hills and Wakaepa, Oliver et al. 1982; Mackinnon 1983) may represent deposition upon the accretionary wedge once it had increased in size and inboard parts first became emergent. Subsequent marine deposition at the toe of the 
wedge, and the resulting reduction in the angle of the taper, would have led to internal deformation of the wedge, thereby structurally incorporating these beds into the upper part of the wedge. The Early Cretaceous (c. $135 \mathrm{Ma}$ ) start of exhumation of the Otago-Marlborough Schist at the inboard margin of the prism may reflect the development of steadystate conditions, where the flux of sediment entering the prism at its toe balances the efflux of material at the back of the prism. The zircon FT ages indicating widespread (now involving Canterbury) exhumation of the Rakaia Terrane from the mid Cretaceous (c. $100 \mathrm{Ma}$ ) may reflect a widening of the prism through subduction accretion at its toe as it grew in a self-similar manner. These middle to Late Cretaceous accreted deposits are represented by the Omaio Belt (Mortimer 1995; Kamp 1999, 2000) and Mangapokia Group in eastern North Island and pre-mid-Piripauan parts of the East Coast Allochthon (Mazengarb \& Harris 1994). The point here is that the timing of exhumation of the inner parts of the prism, extending from c. 135 to $90 \mathrm{Ma}$, identified from thermochronological data in the areas of erosion, match the addition of accretionary sequences of the same age located lower down on the prism. Further work needs to be done to compare the exact timing of Cretaceous exhumation (and the extent to which this was achieved by erosion, tectonic, and other processes or mechanisms) in the inboard region with the timing of Cretaceous sedimentation and accretion at the toe of the contemporary wedge. The aim of this work would be to establish the extent to which the evolution of the prism was continuous versus episodic, and whether or not there was evidence for feedback between erosion high on the prism and sedimentation on the toe of the prism. The feedback is driven by the tendency for development of a critically tapered wedge. All else being equal, the deposition of sediment on the toe of the wedge lowers the taper, causing the wedge to become subcritical. With ongoing convergence, the wedge deforms internally and grows vertically to restore the critical taper angle, which in turn promotes erosion.

This dynamic model for the evolution of the Torlesse Complex also provides a new context in which to conceptualise the Rangitata Orogeny (see description of the expressions of this phase of deformation in Suggate et al. 1978). The deformation would have been driven by subduction, and the structures would have resulted from the internal transport of material in the wedge to restore the critical taper. Exhumation of the Otago-Marlborough Schist reflects, at least in its early history, large-scale upward movement of rock through the inboard part of the wedge. The deformation would date from the time when imbrication started against the New Zealand margin (?Middle Jurassic). There may not be a substantial time break between the Rakaia and Pahau Terranes, the Esk Head Melange being a fossil subduction thrust separating earlier from later accreted sediments. The Rangitata Orogeny is seen traditionally as mainly a Cretaceous feature because the youngest sediments involved in the prism are deformed, but the concept of a dynamic prism allows for continuous deformation throughout the evolution of the prism.

In this scenario, the Rangitata Orogeny is not the result of a terrane collision. The uplift of rocks in the OtagoMarlborough Schist may have extended to involve neighbouring terranes/crust, thereby widening the affect of the "orogeny." Subduction and growth of the Torlesse Complex continued until the end of subduction at c. $85 \mathrm{Ma}$ (Mazengarb \& Harris 1994; Kamp 1999, 2000), meaning that there was at least a 15 m.y. overlap between continental rifting in Westland-Buller, related to the formation of the Lord Howe Rise Rift System, and the end of subduction along the eastern New Zealand convergent margin. The c. $100 \mathrm{Ma}$ start of widespread exhumation in Canterbury is considered a manifestation of prism dynamics and not riftrelated uplift and erosion. The modern analogy for contemporary subduction-driven deformation in the forearc and rift-related extension in the arc and backarc, is the Hikurangi Margin between the Hikurangi Trough and the Taupo Volcanic Zone. Seafloor spreading started in the Tasman Sea around $83 \mathrm{Ma}$, immediately after, and probably as a consequence of subduction ending along the eastern New Zealand margin of Gondwanaland.

\section{CONCLUDING REMARKS}

The Torlesse Complex constitutes an emergent fold-thrust belt that developed at a convergent margin through the growth and imbrication of one or more submarine accretionary wedges. Recent FT thermochronological research on the Torlesse Complex has been aimed at establishing better constraints on the depositional age of various parts of the complex, the maximum paleotemperatures experienced by rocks now at the surface, the timing and style of cooling of rocks within the prism, and the amount and extent of exhumation (Kamp 1997, 1999, 2000; Kamp \& Liddell 2000). This information contributes to a developing understanding of the dynamics of the accretionary complex, the residence time of material in the prism, the time it took for the prism to come to steady state, the time when the inboard margin first became erosional, and the age when subduction ceased and the orogenic wedge became passive.

In this paper, attention has been drawn to the occurrence of a component of ${ }^{40} \mathrm{Ar} /{ }^{39} \mathrm{Ar}$ ages on muscovite from Rakaia rocks that appear to be younger than the Late Triassic paleontologically assigned stratigraphic ages. Published and new zircon FT ages on similar greywacke facies from Arthur's Pass, Rakaia, and Mt Cook localities $>25 \mathrm{~km}$ from the Alpine Fault, are mostly Early Jurassic and compound the apparent conflict with the paleontological ages. While a case is made here for Jurassic deposition of some of these rocks, this is regarded here as an hypothesis that needs to be tested by further work, particularly by FT dating of rocks from established fossil localities. At the same time, existing and any new fossil localities identified, need to be carefully examined to establish if the fossils are indeed autochthonous and faithfully date accumulation of the enclosing terrigenous grains.

A dating limitation of most radiometric methods involving uranium decay and the retention of noble gas daughter products is that closure of the respective geochronological systems is both temperature and time dependent. Systems with closure at high temperatures (e.g., $\mathrm{U}-\mathrm{Pb}$ on zircon at $650-700^{\circ} \mathrm{C}$ ) are not disturbed by subsequent low-intermediate grade metamorphism, such as typically occurs within an accretionary complex, but will accumulate age in the source area long before subsequent 
deposition of derived grains in an accretionary wedge. Depending on the transit time for uplift and erosion, the observed age will be very much a maximum stratigraphic age. Low-temperature radiometric systems, however, such as FT on zircon, with closure between 260 and $210^{\circ} \mathrm{C}$, will record a much shorter source-to-sink transit time, and, potentially, a more realistic depositional age, but this system is more easily disturbed by subsequent heating in a basin or prism.

The simplest interpretation of zircon FT data available for the Rakaia Terrane in Canterbury is that two zircon PAZs have formed, one in the Late Cretaceous and another in the late Cenozoic, which is related to a different tectonic regime. Zircon FT ages for greywacke facies $25-80 \mathrm{~km}$ east of the Alpine Fault in the Arthur's, Rakaia, and Mt Cook transects are considered not to have not been partially annealed, and are considered to retain Early Jurassic detrital ages. This suggests that the component of young muscovite ${ }^{40} \mathrm{Ar} /{ }^{39} \mathrm{Ar}$ ages from similar facies, which are also younger than the paleontological ages assigned to the rocks, are better interpreted as provenance ages rather than partially overprinted ages. These rocks would have taken a shallow transport path from the subduction thrust upwards through the accretionary prism, compared with particles in the Otago Schist, which will have taken a much deeper path.

The young component of ${ }^{40} \mathrm{Ar} /{ }^{39} \mathrm{Ar}$ ages reported for the Rakaia Terrane in the Wellington Belt have recently been interpreted as partially disturbed due to heating in the prism at maximum temperatures in the range $295-305^{\circ} \mathrm{C}$ (Kamp 2000). This component of Ar-Ar ages are now interpreted (here) as provenance ages. The maximum paleotemperatures reached by the Rakaia rocks in the Wellington Belt are more likely to have been in the range $265-282^{\circ} \mathrm{C}$, based on partial annealing of the zircon FT ages and paleotemperature modelling of them (see Kamp 2000, section 5.3). The Wellington rocks have therefore experienced similar maximum paleotemperatures to the Rakaia greywacke rocks in the Waitaki transect (Fig. 10), which will have followed intermediate transport paths within the prism between the deeper ones for Otago Schist and the shallower ones for midCanterbury greywacke.

Interest in, and understanding of, the evolution of New Zealand basement has been advanced by application of the terrane concept over the past 25 years. Critical wedge theory provides a new and alternative model for explaining the character and evolution of the Torlesse Complex, including the Otago-Marlborough Schist component. It differs from the terrane concept in emphasising the unity between different structural elements and geological processes at convergent margins. The dynamic critical wedge model for the evolution of the Torlesse Complex also provides a new and intuitive context for explaining the various expressions of the Rangitata Orogeny.

\section{ACKNOWLEDGMENTS}

I wish to acknowledge John Garver for showing me his new zircon FT etching technique leading to the new data in this paper; Ivan Liddell for technical assistance in the FT lab; and Betty-Ann Kamp for cartographics. I am very grateful to Nick Mortimer, Annette George, and Mark Brandon for considered reviews of this paper, which helped improve it. Funding was provided by the Foundation for Research, Science and Technology, and The University of Waikato.

\section{REFERENCES}

Adams, C. J.; Graham, I. J. 1996: Metamorphic and tectonic geochronology of the Torlesse Terrane, Wellington, New Zealand. New Zealand Journal of Geology and Geophysics 39: 157-180.

Adams, C. J.; Kelley, S. 1998: Provenance of Permian-Triassic and Ordovician metagreywacke terranes in New Zealand: evidence from ${ }^{40} \mathrm{Ar} /{ }^{30} \mathrm{Ar}$ dating of detrital micas. Geological Society of America Bulletin 110: 422-432.

Adams, C. J. D.; Robinson, P. 1993: Potassium-argon age studies of the metamorphism, uplift and cooling in Haast Schist coastal sections south of Dunedin, Otago, New Zealand. New Zealand Journal of Geology and Geophysics 36: 317325.

Adams, C. J. D.; Bishop, D. G.; Gabities, J. E. 1985: Potassiumargon age studies of a low-grade, progressively metamorphosed greywacke sequence, Dansey Pass, South Island, New Zealand. Journal of the Geological Society (London) 142: 339-349.

Adams, C. J.; Barley, M. E.; Fletcher, I. R.; Pichard, A. L 1998: Evidence from U-Pb zircon and ${ }^{40} \mathrm{Ar} /{ }^{39} \mathrm{Ar}$ muscovite detrital mineral ages in metasandstones for movement of the Torlesse suspect terrane around the eastern margin of Gondwanaland. Terra Nova 10: 183-189.

Andrews, P. B.; Speden, I. G.; Bradshaw, J. D. 1976: Lithological and paleontological content of the Carboniferous-Jurassic Canterbury Suite, South Island, New Zealand. New Zealand Journal of Geology and Geophysics 19: 791-819.

Baldwin, S. L.; Lister, G. S. 1998: Thermochronology of the South Cyclades Shear Zone, Ios, Greece: effects of ductile shear in the argon partial retention zone. Journal of Geophysical Research 103: 7315-7336.

Bishop, D. G.; Bradshaw, J. D.; Landis, C. A. 1985: Provisional terrane map of South Island, New Zealand. In: Howell, D. G. ed. Tectonostratigraphic terranes. Circum-Pacific Council for Energy and Mineral Resources Earth Science Series 1: 515-521.

Blome, C. D.; Moore, P. R.; Simes, J. E.; Watters, W. A. 1987: Late Triassic Radiolaria from phosphatic concretions in the Torlesse terrane, Kapiti Island, Wellington. New Zealand Geological Survey Record 18: 103-109.

Bradshaw, J. D.; Andrews, P. B.; Adams, C. J. D. 1981: Carboniferous to Cretaceous on the Pacific margin of Gondwana: the Rangitata phase of New Zealand. In: Cresswell, M. M.; Vella, P. ed. Gondwana 5. Rotterdam, A.A. Balkema. Pp. 217-221.

Brandon, M. T.; Roden-Tice, M. R.; Garver, J. I. 1998: Late Cenozoic exhumation of the Cascadia accretionary wedge in the Olympic Mountains, northwest Washington State. Geological Society of America Bulletin 100: 985-1009.

Burnham, A. K.; Sweeney, J. J. 1989: A chemical kinetic model of vitrinite reflectance maturation. Geochimica et Cosmochimica Acta 53: 2649-2657.

Campbell, J. D.; Warren, G. 1965: Fossil localities of the Torlesse Group in the South Island. Transactions of the Royal Society of New Zealand 3: 99-137.

Cawood, P. A.; Nemchin, A. A.; Leverenz, A.; Saeed, A.; Ballance, P. F. 1999: U/Pb dating of detrital zircons: implications for the provenance record of Gondwana margin terranes. Geological Society of America Bulletin 111: 1107-1119.

Chapple, W. M. 1978: Mechanics of thin-skinned fold- and thrust belts. Geological Society of America Bulletin 89: 11891198.

Coyle, D. A.; Wagner, G. A. 1996: Fission track dating of zircon and titanite from the $9101 \mathrm{~m}$ deep KTB: observed fundamentals of track stability and thermal history reconstruction. Abstract, International Workshop on Fission Track Dating, Gent, 1996. 
Cox, S. C.; Findlay, R. H. 1995: The Main Divide Fault Zone and its role in formation of the Southern Alps, New Zealand. New Zealand Journal of Geology and Geophysics 38 : 489-500.

Crampton, J. S.; Beu, A. G.; Campbell, H. J.; Cooper, R. A.; Strong, C. P.; Wilson, G. J. 1995: An interim New Zealand geological time-scale. Wellington, New Zealand. Institute of Geological \& Nuclear Sciences. 5 p.

Dahlen, F. A. 1990: Critical taper model of fold-and-thrust belts and accretionary wedges. Annual Reviews of Earth and Planetary Sciences 18: 55-99.

Davis, D.; Suppe, J.; Dahlen, F. A. 1983: Mechanics of fold-andthrust belts and accretionary wedges. Journal of Geophysical Research 88: 1153-1172.

Duddy, I. R.; Green, P. F.; Laslett, G. M. 1988: Thermal annealing of fission tracks in apatite 3: variable temperature behaviour. Chemical Geology 73: 25-38.

Galbraith, R. F. 1981: On statistical methods of fission track counts. Mathematical Geology 13: 471-478.

Galbraith, R. F. 1990: The radial plot-graphical assessment of spread in ages. Nuclear Tracks and Radiation Measurements 17: 207-214.

Galbraith, R. F.; Green, P. F. 1991: Estimating the component ages in a finite mixture. Nuclear Tracks and Radiation Measurements 17: 197-206.

Gallagher, K. 1995: Evolving temperature histories from apatite fission-track data. Earth and Planetary Science Letters 136: 421-435.

Gallagher, K.; Brown, R.; Johnston, C. 1998: Fission track analysis and its applications to geological problems. Annual Reviews of Earth and Planetary Sciences 26: 519-572.

Gleadow, A. J. W. 1981: Fission track dating methods: what are the real alternatives? Nuclear Tracks and Radiation Measurements 5: 15-25.

Gleadow, A. J. W.; Duddy, I. R.; Green, P. F.; Hegarty, K. A. 1986: Fission track lengths in the apatite annealing zone and the interpretation of mixed ages. Earth and Planetary Science Letters 78: 245-254.

Gradstein, F. M.; Agterberg, F. P.; Ogg, J. G.; Hardenbol, J.; van Veen, P.; Thierry, J.; Huang, Z. 1994: A Mesozoic timescale. Journal of Geophysical Research 99: 24051-24074.

Grant-Taylor, T. L.; Waterhouse, J. R. 1963: Monotis from the Tararua Range, Wellington, New Zealand. New Zealand Journal of Geology and Geophysics 6: 623-627.

Green, P. F. 1985: A comparison of zeta calibration baselines in zircon, sphene and apatite. Chemical Geology 58: 1-22.

Green, P. F.; Duddy, I. R.; Gleadow, A. J. W.; Tingate, P. R.; Laslett, G. M. 1986: Thermal annealing of fission tracks in apatite 1. Chemical Geology 59: 237-253.

Green, P. F.; Duddy, I. R.; Laslett, G. M.; Hegarty, K.; Gleadow, A. J. W.; Lovering, J. F. 1989: Thermal annealing of fission tracks in apatite 4: quantitative modelling techniques and extensions to geological time-scales. Chemical Geology 79: $155-182$.

Green, P. F.; Hegarty, K. A.; Duddy, I. R.; Foland, S. S.; Gorbachev, V. 1996: Geological constraints on fission track annealing in zircon. Abstract, International Workshop on Fission Track Dating, Gent, 1996.

Gregg, D. R. 1964: Sheet 18-Hurunui. Geological map of New Zealand, scale $1: 250,000$. Wellington, New Zealand. Department of Scientific and Industrial Research.

Hurford, A. J.; Green, P. F. 1982: A guide to fission track dating calibration. Earth and Planetary Science Letters 59: 343-354.
Ireland, T. R. 1992: Crustal evolution of New Zealand: evidence from age distributions of detrital zircons in Western Province paragneisses and Torlesse greywacke. Geochimica et Cosmochimica Acta 56: 911-920.

Kamp, P. J. J. 1997: Paleogeothermal gradient and deformation style, Pacific front of the Southern Alps Orogen: constraints from fission track thermochronology. Tectonophysics 271 : 37-58.

Kamp, P. J. J. 1999: Tracking crustal processes by FT thermochronology in a forearc high (Hikurangi Margin, New Zealand) involving subduction termination and midCenozoic subduction initiation. Tectonophysics 307: 313-343.

Kamp, P. J. J. 2000: Thermochronology of the Torlesse accretionary complex, Welington region, New Zealand. Journal of Geophysical Research 105: 19253-19272.

Kamp, P. J. J.; Liddell, I. J. 2000: Thermochronology of northern Murihuku Terrane, New Zealand, derived from apatite FT analysis. Journal of the Geological Society London 157: 345-354.

Kamp, P. J. J.; Tippett, J. M. 1993: Dynamics of Pacific Plate crust in the South Island (New Zealand) zone of oblique continent-continental collision. Journal of Geophysical Research 98: 16105-16118.

Kamp, P. J. J.; Green, P. F.; White, S. H. 1989: Fission track analysis reveals character of collisional tectonics in New Zealand. Tectonics 8: 169-195.

Laslett, G. M.; Green, P. F.; Duddy, I. R.; Gleadow, A. J. W. 1987: Thermal annealing of fission tracks in apatite 2 : a quantitative analysis. Chemical Geology 65: 1-13.

Lindsay, J. M.; Williams, I. S.; Ireland, T. R.; Smith, I. E. M.; Black, P. M. 1994: Zircon ages in young felsic volcanics and underlying basement in northern New Zealand: implications for rhyolite genesis. Washington DC, U.S. Geological Survey Circular, V.1107: 196.

Lister, G. S.; Baldwin, S. L. 1996: Modelling the effect of arbitrary $\mathrm{P}-\mathrm{T}-\mathrm{t}$ histories on argon diffusion in minerals using the MacArgon program for the Apple Macintosh. Tectonophysics 253: 83-109.

Little, T. A.; Mortimer, N.; McWilliams, M. 1999: An episodic Cretaceous cooling model for the Otago-Marlborough Schist, New Zealand, based on ${ }^{40} \mathrm{Ar} /{ }^{39} / \mathrm{Ar}$ white mica ages. New Zealand Journal of Geology and Geophysics 42: 305-325.

MacKinnon, T. C. 1980: Geology of the Monotis-bearing Torlesse rocks in Temple Basin near Arthur's Pass, South Island, New Zealand. New Zealand Journal of Geology and Geophysics 23: 63-81.

MacKinnon, T. C. 1983: Origin of the Torlesse terrane and coeval rocks, South Island, New Zealand. Geological Society of America Bulletin 94: 967-985.

Mazengarb, C.; Harris, D. H. M. 1994: Cretaceous stratigraphic and structural relations of Raukumara Peninsula, New Zealand: stratigraphic patterns associated with the migration of a thrust system. Annules Tectonica VIII: $100-118$.

Mortimer, N. 1995: Origin of the Torlesse Terrane and coeval rocks, North Island, New Zealand. International Geological Reviews 36: 891-910.

Mortimer, N.; Tulloch, A. J.; Ireland, T. R. 1997: Basement geology of Taranaki and Wanganui Basins, New Zealand. New Zealand Journal of Geology and Geophysics 40: 223-236.

Nathan, S.; Anderson, H. J.; Cook, R. A.; Herzer, R. H.; Hoskins, R. H.; Raine, J. I.; Smale, D. 1986: Cretaceous and Cenozoic sedimentary basins of the West Coast region, South Island, New Zealand. New Zealand Geological Survey Basin Studies report 1. 
Oliver, P. J.; Campbell, J. D.; Speden, I. G. 1982: The stratigraphy of the Torlesse rocks of the Mt Somers area (S81) mid Canterbury. Journal of the Royal Society of New Zealand 12: 243-271.

Sambridge, M. J.; Compston, W. 1994: Mixture modelling of multi-component data sets with application to ion-probe zircon ages. Earth and Planetary Science Letters 128: 373-390.

Suggate, R. P.; Stevens, G. R.; Te Punga, M. T. 1978: The geology of New Zealand. Vol. 1. Wellington, Government Printer.

Tagami, T.; Carter, A.; Hurford, A. J. 1996: Natural long-term annealing of the zircon fission-track system in Vienna Basin deep borehole samples: constraints upon the partial annealing zone and closure temperature. Chemical Geology 130: 147-157.

Tagami, T.; Galbraith, R. F.; Yamada, R.; Laslett, G. M. 1998: Revised annealing kinetics of fission tracks in zircon and geological implications. In: Van de Corte, P.; De Corte, F. ed. Advances in fission-track geochronology. Dordrecht, Kluwer. Pp. 99-112.

Tippett, J. M.; Kamp, P. J. J. 1993: Fission track analysis of the late Cenozoic vertical kinematics of continental Pacific crust, South Island, New Zealand. Journal of Geophysical Research 98: 16119-16148.

Warren, G. 1967: Sheet 17-Hokitika. Geological map of New Zealand, scale 1:250,000. Wellington, New Zealand. Department of Scientific and Industrial Research. 